University of Montana

ScholarWorks at University of Montana

2-1995

\title{
Avian Life-History Evolution in Relation to Nest Sites, Nest Predation, and Food
}

Thomas E. Martin

University of Montana - Missoula, tom.martin@umontana.edu

Follow this and additional works at: https://scholarworks.umt.edu/wildbio_pubs

Part of the Life Sciences Commons

Let us know how access to this document benefits you.

\section{Recommended Citation}

Martin, Thomas E., "Avian Life-History Evolution in Relation to Nest Sites, Nest Predation, and Food" (1995). Wildlife Biology Faculty Publications. 19.

https://scholarworks.umt.edu/wildbio_pubs/19

This Article is brought to you for free and open access by the Wildlife Biology at ScholarWorks at University of Montana. It has been accepted for inclusion in Wildlife Biology Faculty Publications by an authorized administrator of ScholarWorks at University of Montana. For more information, please contact scholarworks@mso.umt.edu. 


\title{
AVIAN LIFE HISTORY EVOLUTION IN RELATION TO NEST SITES, NEST PREDATION, AND FOOD ${ }^{1}$
}

\author{
Thomas E. MARTIN \\ United States National Biological Survey, Montana Cooperative Wildlife Research Unit, \\ University of Montana, Missoula, Montana 59812 USA
}

\begin{abstract}
Food limitation is generally thought to underlie much of the variation in life history traits of birds. I examined variation and covariation of life history traits of 123 North American Passeriformes and Piciformes in relation to nest sites, nest predation, and foraging sites to examine the possible roles of these ecological factors in life history evolution of birds. Annual fecundity was strongly inversely related to adult survival, even when phylogenetic effects were controlled. Only a little of the variation in fecundity and survival was related to foraging sites, whereas these traits varied strongly among nest sites. Interspecific differences in nest predation were correlated with much of the variation in life history traits among nest sites, although energy trade-offs with covarying traits also may account for some variation. For example, increased nest predation is associated with a shortened nestling period and both are associated with more broods per year, but number of broods is inversely correlated with clutch size, possibly due to an energy trade-off. Number of broods was much more strongly correlated with annual fecundity and adult survival among species than was clutch size, suggesting that clutch size may not be the primary fecundity trait on which selection is acting. Ultimately, food limitation may cause trade-offs between annual fecundity and adult survival, but differences among species in fecundity and adult survival may not be explained by differences in food abundance and instead represent differing tactics for partitioning similar levels of food limitation. Variation in fecundity and adult survival is more clearly organized by nest sites and more closely correlated with nest predation; species that use nest sites with greater nest predation have shorter nestling periods and more broods, yielding higher fecundity, which in turn is associated with reduced adult survival.

Fecundity also varied with migratory tendencies; short-distance migrants had more broods and greater fecundity than did neotropical migrants and residents using similar nest sites. However, migratory tendencies and habitat use were confounded, making separation of these two effects difficult. Nonetheless, the conventional view that neotropical migrants have fewer broods than residents was not supported when nest site effects were controlled.

Key words: adult survival; clutch size; cost of reproduction; fecundity; life history traits; nest predation; number of broods; reproductive effort.
\end{abstract}

\section{INTRODUCTION}

A critical issue in the study of life history evolution centers on understanding why species differ in their life history traits (Partridge and Harvey 1988). Most theory assumes that variation in mortality drives evolution of life history variation (Cole 1954, Murphy 1968, Schaffer 1974a, b, Hirshfield and Tinkle 1975, Law 1979, Michod 1979, Charlesworth 1980, Curio 1989) and a variety of empirical studies support this contention (Lynch 1980, Reznick and Bryga 1987, Crowl and Covich 1990, Harvey et al. 1990, Promislow and Harvey 1990, Reznick et al. 1990, Spitze 1991, Stibor 1992, Hutchings 1993). Yet, generality of the assumption that mortality drives life history evolution is unclear (e.g., see Lynch 1992), particularly in birds.

Food has long been considered the major influence on life history evolution in birds through effects on fecundity, and subsequent effects of fecundity on adult

\footnotetext{
' Manuscript received 8 September 1992; revised 16 December 1993; accepted 18 February 1994.
}

survival due to the cost of reproduction (Lack 1948, 1968, Williams 1966a, b, Charnov and Krebs 1974, Murphy and Haukioja 1986, Nur 1990). Food can indeed explain much of the variation in fecundity within species (reviewed in Martin 1987), and although effects of food on interspecific variation are poorly studied, one study showed that some of the variation in fecundity among flycatcher species was correlated with food differences (Murphy 1989). Intraspecific (see Nur 1988, 1990, Roff 1992, Stearns 1992) and interspecific (Bennett and Harvey 1988, Saether 1988) studies also provide some support for existence of a negative correlation between fecundity and survival. On the surface, these results support the long-standing paradigm that food is the major underlying cause of life history variation among bird species. Yet, the issue is not as clear or simple as it first appears.

Studies of the importance of food have focused on intraspecific variation in fecundity. Yet, much intraspecific variation in fecundity is phenotypic and may not reflect genetic correlations or evolutionary re- 
sponses (Price and Liou 1989; also see Schluter and Gustafsson 1993). Even intraspecific experiments can be inappropriate (Reznick 1985). Experiments, such as brood size manipulations, assume that individuals possess the behavioral plasticity to increase their reproductive (feeding) efforts proportional to brood size. Such experiments assume that changes in feeding effort reflect genetic correlations and they may not. Moreover, if reproductive effort is relatively fixed (e.g., Wilbur 1977, Sinervo and Licht 1991, Boggs and Ross 1993), then individuals may not increase effort. For example, Great Tits do not increase their feeding rates with increases in brood size (Smith et al. 1988) and, consequently, survival costs of increased brood size are not manifested (Gustafsson and Sutherland 1988). Phenotypic tests of the cost of reproduction are also problematic because fecundity can be increased by individuals with more food without increasing costs to survival, thereby masking negative covariance between survival and fecundity (Hogstedt 1981, Rose and Charlesworth 1981, Smith 1981, Lande 1982, Tuomi et al. 1983, Reznick 1985). In short, intraspecific studies of phenotypic responses may not test evolutionary responses and do not test causes of interspecific variation (also Brooks and McLennan 1991).

Comparative studies are necessary to examine variation among species, but they only provide correlations and do not distinguish cause and effect (Partridge and Harvey 1988, Harvey and Pagel 1991). Yet, comparative approaches that take phylogenetic relationships into account can allow cautious testing of adaptive hypotheses of the evolution of trait variation and covariation with results that can be tested and confirmed by intraspecific studies (Saether 1988, Harvey et al. 1989, Harvey and Pagel 1991, McLennan 1991, Richman and Price 1992, Roff 1992, Shine and Charnov 1992, Berrigan et al. 1993, Edwards and Naeem 1993).

Here, I test an hypothesis that is contrary to existing conventional views: food is not the major influence on life history variation among bird species. This hypothesis arises because the negative correlation observed between fecundity and survival (O'Connor 1985, Bennett and Harvey 1988, Saether 1988) should not occur if food is the primary cause of variation in fecundity among species; increased food allows increased fecundity without a cost to survival, causing fecundity and survival to covary positively or not at all (e.g., Calow and Woolhead 1977, Hogstedt 1980, 1981, Pettifor et al. 1988, Schulze and Folt 1990). As a result, a negative correlation between fecundity and survival suggests that food effects are of minor importance and should be expressed as deviations from the fecundity-survival function (Fig. 1).

Nest predation is an alternative factor that is thought to influence clutch sizes of tropical (Skutch 1949, 1985, Lack 1954, Kulesza 1990) and hole-nesting birds (Lack 1948, 1954, 1968, Lima 1987, but see Martin and Li 1992, Martin 1993c), but has been given less attention

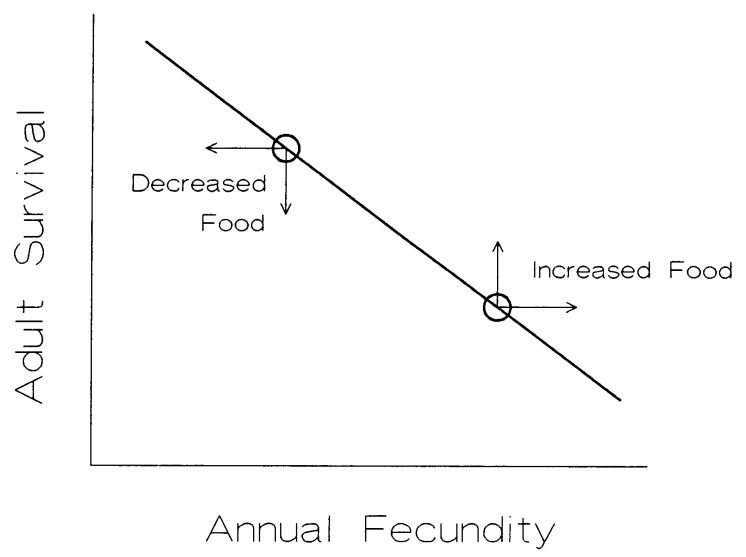

FIG. 1. Hypothetical effects of food when fecundity and annual adult survival are inversely correlated (as found by Saether 1988, Bennett and Harvey 1988). Species differ from each other by occurring at different points (i.e., the different circles) along the inverse function (i.e., the line). These differences in fecundity-survival can yield equivalent fitnesses and, hence, stable populations (Sutherland et al.1986). Differences in food limitation should not cause the inverse function, but rather cause deviations from the function as illustrated by the vectors (arrows): Reduced food abundance should cause reduced fecundity for constant survival (vector to the left) or reduced survival for constant fecundity (downward vector) or both (vector between the two illustrated) causing deviations below the function. In contrast, increased food generally causes higher fecundity for constant survival (vector to the right) or higher survival for constant fecundity (upward vector) or both (vector between the two illustrated) causing deviations above the function.

in other situations. Yet, nest predation is the primary source of nesting mortality (Ricklefs 1969, Martin $1992 a, 1993 a$ ) and can potentially affect life history traits in several ways, while also acting together with food limitation (see Martin 1992b). For example, greater nest predation may favor smaller clutch size, allowing more energy for renesting attempts following failure (Foster 1974, Slatkin 1974, Slagsvold 1982, 1984, Bulmer 1984). This saved energy could also be used for additional brood attempts following success. Consequently, numbers of broods might be expected to covary positively with nest predation and negatively with clutch size, but such relationships are untested. Both clutch size and numbers of broods also may be influenced by length of the nestling period, the latter of which can vary with nest predation (Lack 1948, 1954, 1968, Case 1978, Ricklefs 1984, Martin and Li 1992). In short, both nest predation and food limitation need to be examined relative to variation and covariation of life history traits.

Of course, nest predation and food are not the only selective forces that may affect fecundity. Species that colonize early successional habitats are thought to reproduce at a higher rate than species using more stable habitat conditions (MacArthur and Wilson 1967, Pianka 1970). Also, neotropical migrants are thought to have lower reproductive rates than residents or short- 
distance migrants, potentially making them more vulnerable to habitat disturbance (Whitcomb et al. 1981, Robbins et al. 1989a, b). Yet, previous comparative analyses of migrants and residents did not differentiate nest types (e.g., Whitcomb et al. 1981, O'Connor 1985, Dobson 1990), which may yield biased results because some nest types (e.g., cavity vs. open) are not equally represented among migrants and residents (Haartman 1957, 1968) and life history traits can differ among these nest types (Lack 1948, 1954, Martin and Li 1992).

Here, I examine variation and covariation in clutch size, number of broods, duration of the nestling period, nest predation, annual fecundity, and adult survival for 123 bird species. I compare these life history traits among five nest sites (excavators, non-excavators, ground nesters, shrub nesters, and canopy nesters) that differ in nest predation rates (Martin and Li 1992, Martin $1992 a, 1993 a$ ). I also compare five foraging sites (bark, ground-, shrub-, and canopy-gleaners, and aerial insectivores) that are thought to differ in food resources. I compare life history traits among nest sites and foraging sites to assess the possible association with nest predation and food. I test whether neotropical migrant and forest species have lower fecundity than resident/short-distance migrants and shrub/grassland species, respectively. I focus on Passeriformes and $\mathrm{Pi}$ ciformes in North America because they are similar in habitat (primarily in terrestrial habitats), breeding sociality (generally territorial), age of first reproduction (usually breed in the first year), and food use (mostly insectivorous during breeding).

\section{Methods}

Estimates of clutch size, numbers of broods, duration of the nestling period, adult survival, overall nesting success, and nesting failure due to predation were obtained from as many studies as could be found in the literature. Only studies on natural nests were included (e.g., nest box studies were excluded) because artificial nests such as nest boxes can alter clutch sizes and nesting mortality (Nilsson 1984, 1986, Møller 1989). Only studies of species with sample sizes of $>15$ nests were included, but most studies reported data on considerably larger sample sizes. Numbers of broods refers to the number of successful broods attempted per year. Few studies provided detailed quantitative estimates of numbers of broods; thus, they were classified to the nearest 0.5 broods. For example, if a species was observed to produce second broods consistently but infrequently, it was classified as 1.5 broods, whereas if it was found to frequently produce second broods, it was classifed as 2.0 broods. Only a small fraction of studies $(26 \%, n=89)$ provided Mayfield $(1961,1975)$ estimates of nest predation, so all estimates of predation are reported as the simple percentage of total nests lost to predation. Use of simple percentages incorporates biases from variation among investigators in timing and completeness of nest location activities and thereby increases statistical noise with respect to predation rates. Predation rates are reported on a per-nest basis because of possible biases in determining causes of partial brood losses and because predation usually causes loss of the entire brood (Lack 1954, Nice 1957, Ricklefs 1969, Nilsson 1984, Møller 1989).

Annual survival estimates for adults were recalculated using Farner's (1949, 1955) method whenever possible to standardize estimation methods as much as possible. When the first year after capture, or any single calendar year, differed dramatically in comparison to all remaining years, it was excluded from estimates. Survival values calculated by methods other than Farner's method (e.g., Roberts 1971; or the method derived jointly by Jolly [1965] and Seber [1965]) were taken as directly reported by authors. Some studies had supplemental food and these were excluded whenever additional estimates were available for other populations of the same species without supplemental food. Estimation of fecundity is generally easier than survival (Clobert and Lebreton 1991). Adult survival estimates in passerines are largely based on recapture rates, which can be a biased estimator of survival because it includes both survival and probability of recapturing (or resighting) birds (Lebreton et al. 1982). However, where recapture probability is high, then survival estimates are reasonably unbiased. Color-banding studies provided much of the data presented here and such studies where investigators intensively band and look for individuals may yield high recapture probabilities and reasonable estimates of survival. Indeed, survival estimates from Jolly-Seber (Cormack 1964, Jolly 1965, Seber 1965) models, which take recapture probabilities into account, did not differ from estimates under other methods when compared among nest sites and migratory classifications (Martin 1993b), suggesting that estimates are reasonable relative to the broad ecological comparisons made here. Any biases that do exist should simply increase statistical noise and reduce the strength of relationships.

Latitude where each study was conducted was obtained to the nearest degree. Only a small number of species had data from more than one study, thereby eliminating the ability to examine within-species variation. Consequently, when more than one study provided information for a species, the data were averaged across studies. Confidence in the data as representative of the true central tendency for a species is reduced for those species represented by a single study given that traits such as clutch size, nestling period, number of broods, and nest predation can vary geographically and with habitat disturbance. I assume that any such biases are randomly distributed across species such that statistical noise is increased and observable patterns must be robust and conservative in their correlations.

Species were assigned to the habitat types and nest sites that they used most commonly. Broad categories were used to reduce fragmenting the sample size. Hab- 
itat types included forest, shrub/grassland, and marsh. Data for only seven species were obtained for marsh habitats and they did not differ from shrub/grassland habitats. As a result, marsh was combined with shrub/ grassland leaving two habitats (shrub/grasslands and forests) for comparisons. Nests were classified as shrub nests if they were $<3 \mathrm{~m}$ above the ground and as subcanopy/canopy nests if higher. Most species only used a single habitat or nest site, but some species were more variable (e.g., ground-nesting species that also nested above the ground or shrubland species that also used forest). Such species added statistical noise to analyses.

To provide an independent test of relationships found in analyses of the literature data set, I re-analyzed the data of Whitcomb et al. (1981), hereafter referred to as the Whitcomb data, for clutch size, numbers of broods, and longevity relative to migratory tendencies and nest sites. I only included species in Passeriformes and Piciformes. I made two changes to the Whitcomb data because information reported in the literature indicated more appropriate values. Clutch size for Blackand-White Warblers (scientific names are in Appendix 2) was set as 4.85 eggs based on data from egg collections (Martin 1988c) and Arkansas (P. Li and T. E. Martin, unpublished data). Clutch size for Pileated Woodpecker was set as 3.8 eggs based on data in Koenig (1987).

One of the life history traits that differed among taxa was length of the nestling period. I was particularly interested in differences in the nestling period among ground, shrub, and canopy layers because of nest predation differences among these vegetation layers (Martin 1993a). Two subfamilies (Parulinae, Emberizinae) include the vast majority of ground-nesting species in the Passeriformes in North America. Thus, I analyzed duration of the nestling period for each of these subfamilies separately to minimize phylogenetic effects. I used the midpoint in the range of values provided by Ehrlich et al. (1988) and Terres (1980). This analysis includes an assumption that this value is correlated with field-measured values. I tested this assumption with data that I obtained from the literature for both subfamilies together and found strong correspondence $(r$ $=0.786, P<0.0001, n=36$ ), thereby corroborating the assumption.

All percentage data were arcsine-transformed for statistical analyses and body mass (fresh mass was considered throughout this study) was log-transformed; body fresh mass was taken from Dunning (1984). Except when specified otherwise, all analyses were either analysis of covariance (ANCOVA) or regression analyses. For all ANCOVAs, slopes were fitted separately when heterogeneous. Body fresh mass was included as a covariate in all ANCOVAs and partial correlations because the traits examined here can vary with body mass and it provides a potential means for controlling possible physiological differences (e.g., Saether 1987, 1989, Dobson 1990). ANCOVA was used to examine differences in life history traits among factors (nest sites, foraging sites, migratory classifications, and habitat types), while controlling possible covariates such as body mass, latitude, and nest predation. Partial correlations were used to explore covariation of traits while controlling body mass and other possible covariates. Specific tests are detailed in the Results section.

Phylogenetic relationships potentially create a problem of non-independence among some species because closely-related species may exhibit similar traits (Felsenstein 1985, Grafen 1989, Harvey and Pagel 1991, Martins and Garland 1991). As a result, all data were also analyzed with the independent contrast method of Felsenstein (1985) and with Pagel's (1992) approach to incompletely resolved phylogenies, based on Purvis (1991), to control for possible phylogenetic effects. This approach uses the full phylogenetic information at all taxonomic levels. The phylogenetic hypothesis was constructed based on the most recent information available (Avise et al. 1980a, b, $c$, Zink 1982, Johnson and Zink 1983, Zink and Johnson 1984, Lanyon 1985 , Marten and Johnson 1986, Bledsoe 1988, Johnson et al. 1988, Sibley and Ahlquist 1990, Zink and Avise 1990, Zink and Dittman 1991, 1993, Zink et al. 1991a, $b$, Bermingham et al. 1992, Webster 1992, Gill et al. 1993, Tamplin et al. 1993). I did not have consistent estimates of branch lengths because the data came from different studies using differing methods. As a result, branch lengths were obtained by assuming ages of taxa were proportional to the number of species they contain, following Grafen (1989). A second set of analyses were conducted with branch lengths set as equal, reflecting a punctuational model. These latter analyses yielded essentially the same results as when using the Grafen (1989) estimators, indicating the robust nature of these analyses (also see Martins and Garland 1991). Consequently, only the results obtained under the Grafen (1989) method are reported. The independent contrasts approach computes differences between related taxa at each node working back through the entire phylogenetic tree because such differences represent independent evolution (Felsenstein 1985). All relationships examined using independent contrasts were regressions, in which the regression line was forced through the origin because the contrasts were standardized (detailed justification in Garland et al. 1992). Regression models were used on the phylogeneticallytransformed data (independent contrasts) to simulate the ANCOVAs performed on the phylogenetically-untransformed data. In particular, covariates were included by forcing them first into the regression model. Next, categorical "factors" (e.g., nest sites, foraging sites, habitat types, or migratory classifications) were tested by creating $n-1$ dummy variables for each factor and these dummy variables were phylogenetically-transformed. The cumulative change in Sums of Squares when these dummy variables were entered as a group 
TABLE 1. Analysis of covariance of life history traits among Passeriformes and Piciformes species, where data were not corrected for phylogenetic history. Analyses examine differences in life history traits (dependent variables) among potential ecological influences while controlling for possible covariates. Sample sizes refer to numbers of species.

\begin{tabular}{|c|c|c|c|c|c|c|c|c|c|c|}
\hline & \multicolumn{10}{|c|}{ Dependent variables } \\
\hline & \multicolumn{2}{|c|}{$\begin{array}{l}\text { Nest predation } \\
n=101\end{array}$} & \multicolumn{2}{|c|}{$\begin{array}{c}\text { Clutch size } \\
n=101\end{array}$} & \multicolumn{2}{|c|}{$\begin{array}{c}\text { No. of broods } \\
n=98\end{array}$} & \multicolumn{2}{|c|}{$\begin{array}{l}\text { Annual fecundity } \\
n=98\end{array}$} & \multicolumn{2}{|c|}{$\begin{array}{c}\text { Annual fecundity } \\
n=65\end{array}$} \\
\hline & $F$ & $P$ & $F$ & $P$ & $F$ & $P$ & $F$ & $P$ & $F$ & $P$ \\
\hline \multicolumn{11}{|l|}{ Covariates } \\
\hline $\begin{array}{l}\text { Body fresh mass } \\
\text { Predation } \\
\text { Latitude } \\
\text { Adult survival }\end{array}$ & $\begin{array}{c}0.01 \\
\cdots \\
0.35 \\
\cdots\end{array}$ & $\begin{array}{c}0.977 \\
\cdots \\
0.553 \\
\cdots\end{array}$ & $\begin{array}{r}4.67 \\
26.53 \\
0.02 \\
\cdots\end{array}$ & $\begin{array}{l}0.033 \\
0.000 \\
0.886 \\
\quad \cdots\end{array}$ & $\begin{array}{r}2.96 \\
29.24 \\
2.49 \\
\cdots\end{array}$ & $\begin{array}{l}0.089 \\
0.000 \\
0.119 \\
\quad \cdots\end{array}$ & $\begin{array}{l}0.01 \\
5.89 \\
2.95 \\
\cdots\end{array}$ & $\begin{array}{c}0.911 \\
0.017 \\
0.090 \\
\cdots\end{array}$ & $\begin{array}{r}17.16 \\
1.67 \\
4.63 \\
117.37\end{array}$ & $\begin{array}{l}0.000 \\
0.202 \\
0.036 \\
0.000\end{array}$ \\
\hline \multicolumn{11}{|l|}{ Factors } \\
\hline $\begin{array}{l}\text { Habitat type } \\
\text { Migratory classification } \\
\text { Foraging site } \\
\text { Nest site }\end{array}$ & $\begin{array}{l}0.49 \\
0.56 \\
0.46 \\
7.72\end{array}$ & $\begin{array}{l}0.485 \\
0.571 \\
0.765 \\
0.000\end{array}$ & $\begin{array}{r}2.75 \\
2.88 \\
1.47 \\
14.25\end{array}$ & $\begin{array}{l}0.101 \\
0.062 \\
0.220 \\
0.000\end{array}$ & $\begin{array}{l}4.70 \\
0.55 \\
2.09 \\
4.57\end{array}$ & $\begin{array}{l}0.033 \\
0.579 \\
0.090 \\
0.002\end{array}$ & $\begin{array}{r}2.72 \\
0.36 \\
3.92 \\
13.60\end{array}$ & $\begin{array}{l}0.103 \\
0.701 \\
0.006 \\
0.000\end{array}$ & $\begin{array}{r}0.32 \\
2.47 \\
13.67 \\
1.18\end{array}$ & $\begin{array}{l}0.576 \\
0.095 \\
0.000 \\
0.331\end{array}$ \\
\hline & \multicolumn{2}{|c|}{$R=0.701$} & \multicolumn{2}{|c|}{$R=0.761$} & \multicolumn{2}{|c|}{$R=0.719$} & \multicolumn{2}{|c|}{$R=0.757$} & \multicolumn{2}{|c|}{$R=0.907$} \\
\hline
\end{tabular}

was then examined to determine statistical significance of a factor.

\section{RESUlts}

\section{Nest predation and nest success}

Nest predation may vary negatively with latitude (e.g., Ricklefs 1969, Kulesza 1990), so latitude was included as a covariate in analyses of nest predation. However, latitude was not a significant covariate of nest predation for the data examined here (Table 1). Nest predation also did not covary with differences in body mass among species (Table 1). When all four main factors were included, nest predation did not differ among habitat types, migratory classifications, or foraging sites, but did differ strongly among nest sites (Table 1). The same results were obtained when phylogeny was controlled, where nest predation differed only among nest types (Table 2). The importance of nest sites for differences in nest predation are clear from examination of mean nest predation rates among nest sites in each habitat (Table 3 ).

Nesting success $(n=103)$ differed among nest sites $(F=14.0, P<0.0001)$ and showed the same, but inverse, patterns as for nest predation (Table 3 ).

\section{Clutch size}

If clutch size varies inversely with nest predation, then Table 3 suggests that clutch size should vary in the order: excavators $>$ non-excavators $=$ ground nesters $>$ canopy nesters $>$ shrub nesters. Both the literature and Whitcomb data sets showed the predicted pattern of clutch size among nest sites (Table 4) with exception of non-excavators, which had larger clutch sizes than predicted, based on their rates of nest predation (compare Tables 3 and 4). As a result, predation was a significant covariate of clutch size (Table 1) and exclusion of non-excavators yielded higher partial correlations between clutch size and nest predation $\left(r_{p}=\right.$

TABLE 2. Analysis of covariance using a regression approach (see Methods) of life history traits among Passeriformes and Piciformes species, while correcting for possible phylogenetic effects using Felsentein's (1985) independent contrasts. Analyses examine differences in life history traits (dependent variables) among potential ecological influences while controlling for possible covariates. Sample sizes refer to numbers of independent contrasts.

\begin{tabular}{|c|c|c|c|c|c|c|c|c|c|c|}
\hline & \multicolumn{10}{|c|}{ Dependent variables } \\
\hline & \multicolumn{2}{|c|}{$\begin{array}{l}\text { Nest predation } \\
\quad n=92\end{array}$} & \multicolumn{2}{|c|}{$\begin{array}{c}\text { Clutch size } \\
n=92\end{array}$} & \multicolumn{2}{|c|}{$\begin{array}{c}\text { No. of broods } \\
n=92\end{array}$} & \multicolumn{2}{|c|}{$\begin{array}{c}\text { Annual fecundity } \\
n=92\end{array}$} & \multicolumn{2}{|c|}{$\begin{array}{c}\text { Annual fecundity } \\
n=62\end{array}$} \\
\hline & $F^{*}$ & $P$ & $F$ & $P$ & $F$ & $P$ & $F$ & $P$ & $F$ & $P$ \\
\hline \multicolumn{11}{|l|}{ Covariates } \\
\hline Body fresh mass & 0.27 & 0.602 & 0.05 & 0.832 & 1.47 & 0.228 & 1.65 & 0.203 & 3.95 & 0.052 \\
\hline Predation & $\cdots$ & $\cdots$ & 2.95 & 0.089 & 10.30 & 0.002 & 2.75 & 0.101 & 7.82 & 0.007 \\
\hline Adult survival & $\cdots$ & $\cdots$ & $\cdots$ & $\cdots$ & $\cdots$ & $\cdots$ & $\cdots$ & $\cdots$ & 124.34 & 0.000 \\
\hline \multicolumn{11}{|l|}{ Factors } \\
\hline Habitat type & 1.70 & 0.196 & 0.44 & 0.507 & 1.61 & 0.208 & 0.33 & 0.565 & 0.05 & 0.828 \\
\hline Migratory classification & 1.76 & 0.180 & 11.59 & 0.000 & 3.08 & 0.051 & 8.42 & 0.001 & 0.48 & 0.619 \\
\hline Foraging site & 0.52 & 0.720 & 0.97 & 0.428 & 0.50 & 0.732 & 1.13 & 0.350 & 2.58 & 0.049 \\
\hline \multirow[t]{2}{*}{ Nest site } & 6.51 & 0.000 & 23.17 & 0.000 & 9.91 & 0.000 & 18.49 & 0.000 & 1.29 & 0.288 \\
\hline & \multicolumn{2}{|c|}{$R=0.549$} & \multicolumn{2}{|c|}{$R=0.813$} & \multicolumn{2}{|c|}{$R=0.685$} & \multicolumn{2}{|c|}{$R=0.778$} & \multicolumn{2}{|c|}{$R=0.886$} \\
\hline
\end{tabular}

\footnotetext{
$* F$ value for the change in sums-of-squares.
} 
TABlE 3. Percentage of nests that were lost to predators (\% nest predation) or that fledged at least one young (\% nest success) among nest sites in two habitat types. Data represent means $\pm 1 \mathrm{SE}$.

\begin{tabular}{|c|c|c|c|c|}
\hline \multirow[b]{2}{*}{ Nest site } & \multicolumn{2}{|c|}{ Forest habitats } & \multicolumn{2}{|c|}{ Shrub/grassland habitats } \\
\hline & $\begin{array}{l}\text { Nest predation } \\
(\%)\end{array}$ & $\begin{array}{l}\text { Nest success } \\
(\%)\end{array}$ & $\begin{array}{c}\text { Nest predation } \\
(\%)\end{array}$ & $\begin{array}{c}\text { Nest success } \\
(\%)\end{array}$ \\
\hline Excavator & $11.0 \pm 2.80(7)^{*}$ & $85.3 \pm 2.44(11)$ & $\cdots$ & $\ldots$ \\
\hline Ground & $30.7 \pm 1.48(10)$ & $63.3 \pm 2.90(11)$ & $38.9 \pm 2.78(15)$ & $44.4 \pm 2.62(14)$ \\
\hline Canopy & $36.5 \pm 1.90(17)$ & $47.0 \pm 3.37(18)$ & $\ldots$ & $\begin{array}{c}\text {. } \\
\ldots\end{array}$ \\
\hline Shrub & $48.5 \pm 2.91(13)$ & $45.5 \pm 3.06(14)$ & $43.7 \pm 2.29(26)$ & $40.1 \pm 2.61(30)$ \\
\hline Non-excavator & $31.4 \pm 3.34(10)$ & $62.9 \pm 3.16(10)$ & $37.5 \pm 7.48(3)$ & $54.8 \pm 5.76(5)$ \\
\hline
\end{tabular}

* Sample size $=$ number of species.

$-0.438, P<0.0001)$ than when non-excavators were included $\left(r_{p}=-0.357, P=0.0006\right)$. Nonetheless, nest site explained additional variation in clutch size once nest predation was controlled (Table ${ }^{*} 1$ ). Clutch size also differed marginally among migratory classifications, but neither foraging site or habitat type explained any additional variation in clutch size (Table 1). Nest predation and nest site together explained $51.1 \%$ of the variation in clutch size. The differences in clutch size among nest sites, and the lack of difference among habitat types within nest sites, are clear from Table 4.

Results differed slightly once phylogenetic effects were removed. Clutch size continued to vary most strongly among nest sites (Table 2), but the importance of nest predation was reduced dramatically, while phylogenetically-transformed clutch sizes differed among migratory classifications (Table 2). Foraging sites and habitat types continued to be unimportant. Thus, both untransformed and phylogenetically-transformed results show that considerable variation in clutch size was related to differences in nest sites, migratory classifications, and possibly nest predation, but not to differences in foraging locations or habitat types.

\section{Numbers of broods}

Nest predation was a highly significant positive covariate of numbers of broods (Table 1), as can be seen by their correspondence among nest sites (compare Tables 3 and 4). Partial correlation analysis that corrected for body mass indicated that nest predation was more highly correlated with numbers of broods $\left(r_{p}=0.530\right.$, $P<0.0001$; Fig. 2a) than with clutch size (see section entitled Clutch size). The correlation betwen nest predation and numbers of broods remained strong even when phylogeny was controlled $(r=0.322, P=$ 0.0018 ; Fig. 2b). Indeed, three points were outliers (see Fig. 2b), all of which represented independent contrasts for wrens (Troglodytidae), and exclusion of these outliers yielded a strong correlation $(r=0.503, P<$ 0.0001 ).

Species with higher nest predation rates produced more broods, but more broods were associated with smaller clutch sizes $\left(r_{p}=-0.321, P=0.0014\right.$, Fig. 3a). Non-excavators were outliers (see Fig. 3a) and exclusion yielded a higher correlation between numbers of broods and clutch size $\left(r_{p}=-0.467, P<\right.$

TABLE 4. Data gathered from the literature on annual adult survival (percentage of individuals surviving between years), annual fecundity (product of numbers of broods and clutch size), numbers of broods (numbers of successful broods attempted per year), and clutch size of Passeriformes and Piciformes species that nested in different sites and habitat types. Data are also summarized from Whitcomb et al. (1981). Note that the Adult survival column is actually longevity for the Whitcomb et al. (1981) data. Data represent means \pm 1 SE.

\begin{tabular}{|c|c|c|c|c|}
\hline Nest site & Adult survival $(\%)$ & Annual fecundity & $\begin{array}{l}\text { Broods } \\
\text { (No./yr) }\end{array}$ & $\begin{array}{c}\text { Clutch size } \\
\text { (No. eggs per nest) }\end{array}$ \\
\hline \multicolumn{5}{|c|}{ Forest habitat $(n=73)$} \\
\hline Excavator & $0.668 \pm 0.020(8)^{*}$ & $4.99 \pm 0.404(11)$ & $1.09 \pm 0.061$ & $4.56 \pm 0.234$ \\
\hline Ground & $0.627 \pm 0.018(8)$ & $5.14 \pm 0.302(13)$ & $1.19 \pm 0.107$ & $4.44 \pm 0.167$ \\
\hline Canopy & $0.609 \pm 0.030(10)$ & $5.89 \pm 0.602(18)$ & $1.42 \pm 0.101$ & $4.14 \pm 0.284$ \\
\hline Shrub & $0.529 \pm 0.058(12)$ & $6.70 \pm 0.442(15)$ & $1.83 \pm 0.116$ & $3.66 \pm 0.079$ \\
\hline Non-excavator & $0.435 \pm 0.017(14)$ & $9.11 \pm 0.594(16)$ & $1.63 \pm 0.107$ & $5.71 \pm 0.278$ \\
\hline \multicolumn{5}{|c|}{ Shrub/grassland habitat $(n=50)$} \\
\hline Ground & $0.569 \pm 0.024(8)$ & $6.93 \pm 0.534(15)$ & $1.63 \pm 0.150$ & $4.37 \pm 0.146$ \\
\hline Shrub & $0.532 \pm 0.013(20)$ & $7.75 \pm 0.345(28)$ & $2.07 \pm 0.088$ & $3.72 \pm 0.110$ \\
\hline Non-excavator & $0.444 \pm 0.018(3)$ & $8.95 \pm 1.281(5)$ & $2.00 \pm 0.500$ & $4.54 \pm 0.510$ \\
\hline \multicolumn{5}{|c|}{ Whitcomb data $(n=57)$} \\
\hline Excavator & $185.8 \pm 29.34(5)$ & $4.55 \pm 0.452(5)$ & $1.00 \pm 0.000$ & $4.55 \pm 0.452$ \\
\hline Ground & $199.0 \pm 29.66(6)$ & $4.80 \pm 0.345(6)$ & $1.08 \pm 0.083$ & $4.46 \pm 0.218$ \\
\hline Canopy & $159.4 \pm 10.80(16)$ & $4.71 \pm 1.750(16)$ & $1.22 \pm 0.102$ & $3.87 \pm 0.171$ \\
\hline Shrub & $127.3 \pm 7.31$ & $7.15 \pm 2.493(22)$ & $1.95 \pm 0.131$ & $3.65 \pm 0.095$ \\
\hline Non-excavator & $108.5 \pm 8.76$ & $8.23 \pm 2.898(8)$ & $1.63 \pm 0.206$ & $5.15 \pm 0.270$ \\
\hline
\end{tabular}

* Sample size $=$ number of species; sample sizes are the same for annual fecundity, numbers of broods, and clutch size. 
$0.0001)$. Again, this relationship remained when phylogeny was controlled $(r=-0.313, P=0.0025$, Fig. $3 b)$. The independent contrast between Red-breasted and White-breasted Nuthatches was an outlier (see Fig. $3 \mathrm{~b})$ and exclusion confirmed the strong nature of the relationship ( $r=-0.487, P<0.0001)$. Thus, these results indicate that species that experience higher nest predation rates produce more broods, but smaller clutch sizes.

Once variation in nest predation was controlled, nest sites could still account for much additional variation in numbers of broods (Table 1). Numbers of broods also differed among habitat types, with more broods in shrub/grasslands than in forests, and this result was clear within any nest type represented in both habitats (Table 4). However, numbers of broods did not differ among foraging sites or migratory classifications (Table 1). Thus, as with clutch size, variation in numbers of broods was explained by nest sites and nest predation, but not by foraging sites.

When phylogenetic effects were controlled, it was still possible to explain the greatest amount of variation

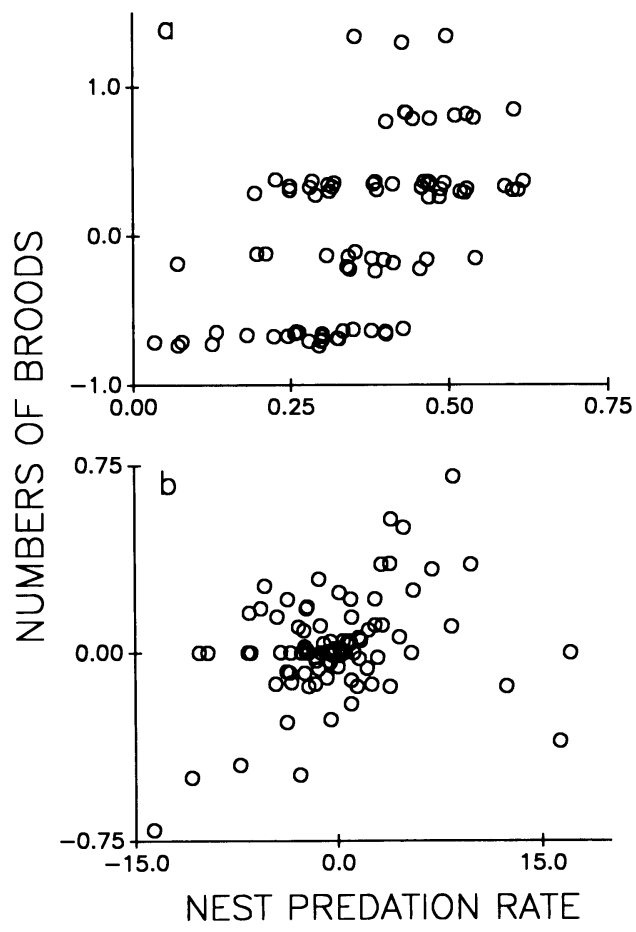

FIG. 2. Scattergrams of the standardized residuals (i.e., partial correlations) of numbers of broods corrected for body fresh mass relative to nest predation (percentage of nests lost to predators) in Passeriformes and Piciformes. Numbers of broods are related to nest predation when, (a) phylogeny is not controlled, by the equation: Numbers of Broods $=0.641$ $+0.173 \log ($ fresh mass $[\mathrm{g}])+2.155 \arcsin ($ Nest Predation [\%]), $n=98$ species; and (b) when phylogeny is controlled using independent contrasts, by the equation: Numbers of Broods $=0.363 \log ($ fresh mass $[\mathrm{g}])+0.014$ Nest Predation [\%], $n=91$ independent contrasts.

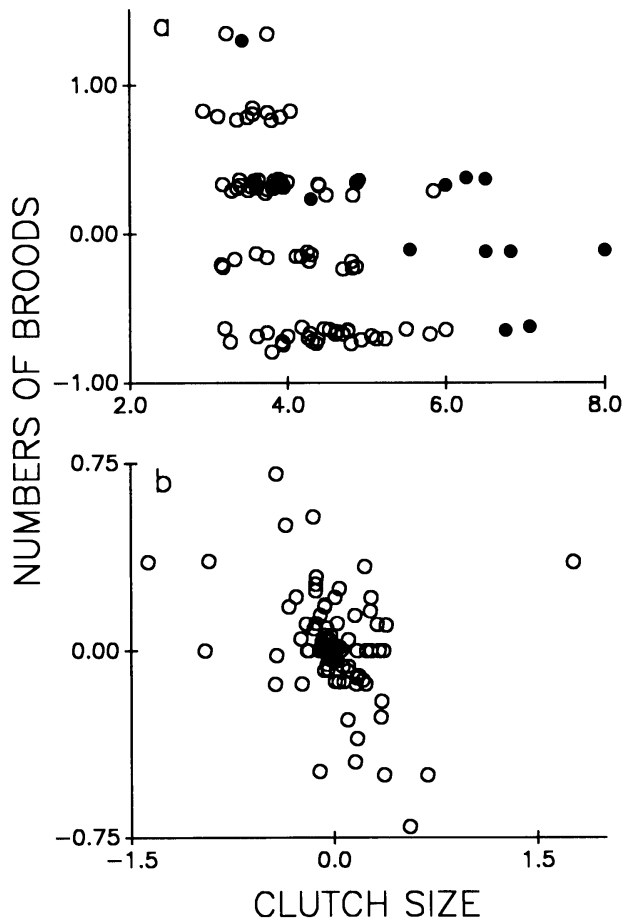

FIG. 3. Scattergrams of the standardized residuals (i.e., partial correlations) of numbers of broods (numbers of successful broods attempted per year) corrected for body fresh mass vs. clutch size corrected for body fresh mass in Passeriformes and Piciformes. Numbers of broods are related to clutch size by the following equations when (a) phylogeny is not controlled and non-excavators (solid circles) are included: Numbers of Broods $=2.376+0.085 \log$ (fresh mass [g]) -0.195 Clutch size (eggs), $n=98$ species, vs. when non-excavators are not included: Numbers of Broods $=2.987$ $+0.207 \log ($ fresh mass $[\mathrm{g}])-0.402$ Clutch size (no. eggs), $n=85$ and (b) phylogeny is controlled using independent contrasts: Numbers of Broods $=0.444 \log ($ fresh mass $[\mathrm{g}])-$ 0.195 Clutch size (no. eggs), $n=91$ independent contrasts.

in numbers of broods by nest predation and nest sites, and foraging sites still appeared to be unimportant (Table 2). However, habitat type became insignificant, while migratory classification became significant ( Table 2). This switch in significance of the latter two factors potentially reflects a confounding that is difficult to separate; shrub/grassland habitats include a preponderance of short-distance migrants, many of which are taxonomically-related. In particular, most species in the Emberizinae use shrub/grasslands and are shortdistance migrants and multi-brooded. Thus, multibroodedness in this group could be related to either habitat (early successional) or migratory classification (short-distance migrant), but analysis of phylogenetically-controlled data suggest that migratory classification is more important (Table 2). This result is somewhat apparent by comparisons within habitats; for example, within forests, long-distance migrants (e.g., Tanagers and Grosbeaks) have fewer broods than shortdistance relatives that use the same habitat (e.g., Jun- 


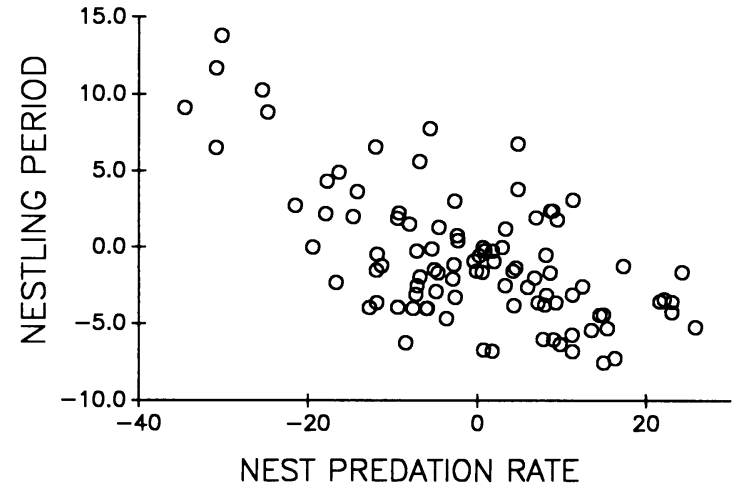

FIG. 4. Scattergram of the standardized residuals (i.e., partial correlations) of nestling period (numbers of days nestlings remain in the nest) corrected for body fresh mass and latitude relative to nest predation (percentage of nests lost to predators) corrected for latitude in Passeriformes and Piciformes. Nestling period is related to nest predation by the equation: Nestling period $(d)=20.196+6.111 \log ($ fresh mass $[\mathrm{g}])-0.227$ Latitude (degrees North) - 15.293 arc$\sin ($ Nest predation $[\%]), n=101$ species.

cos). This difference is particularly significant because it is opposite the one expected based on their nest sites; Juncos are ground nesters and Tanagers and Grosbeaks are sub-canopy/canopy nesters and, hence, Juncos should have fewer rather than more broods based on general patterns of numbers of broods among nest sites (Table 4). The pattern is not as apparent within shrub/ grasslands. At least one long-distance migrant (Dickcissel) has fewer broods than short-distance relatives (many species), but Indigo Bunting, which is a longdistance migrant, has as many broods as short-distance relatives (Appendix 1) and provides a counterexample. The latter comparison may suggest that habitat does exert some influence, but that the small sample sizes that result once habitat, migratory classification, and nest site effects are partitioned reduce the power of analyses.

\section{Duration of the nestling period}

Duration of the nestling period increased with body mass $\left(r_{p}=0.444, P<0.0001, n=119\right)$ but decreased with latitude $\left(r_{p}=-0.341, P=0.0002\right)$ when both were entered into a partial correlation analysis. Once body mass and latitude were controlled, nestling period still decreased with increased nest predation rate $\left(r_{p}=\right.$ $-0.506, P<0.0001$; Fig. 4). Moreover, with both body mass and latitude controlled and clutch size and numbers of broods entered into a partial correlation analysis simultaneously, shorter nestling periods were associated with more broods $\left(r_{p}=-0.441, P<0.0001\right)$ and smaller clutches $\left(r_{p}=0.278, P=0.0025\right)$, but nestling period had a much clearer association with numbers of broods (see Fig. 5). Similar results were obtained when phylogeny was controlled. Longer nestling periods were associated with lower latitudes $\left(r_{p}=-0.416, P\right.$
$<0.0001, n=88)$ and larger body masses $\left(r_{p}=0.343\right.$, $P=0.0012)$. With both controlled, nestling period still decreased with increasing nest predation $\left(r_{p}=-0.244\right.$, $P=0.023)$. Shorter nestling periods were also correlated with more broods $\left(r_{p}=-0.287, P=0.0076\right)$, but not with clutch sizes $\left(r_{p}=-0.131, P=0.233\right)$. In all cases, one or two outliers reduced the strength of each relationship. In the case of clutch size, exclusion of two outliers caused the relationship to become positive, but still nonsignificant, indicating the weak or nonexistent relationship between nestling period and clutch size. When latitude, body mass, and nest predation were included as covariates, residual variation in nestling period was still explained by nest sites $(F$ $=17.19, P<0.0001)$; nestling period varied in the order: shrub nesters $<$ ground nesters $<$ canopy nesters $<$ non-excavators $<$ excavators.

The correlation of nest predation with nestling period could simply arise from the difference between open nesters vs. cavity nesters: open-nesting species have higher nest predation rates (Table 3) and shorter nestling periods (Appendix 1). If nestling period decreases

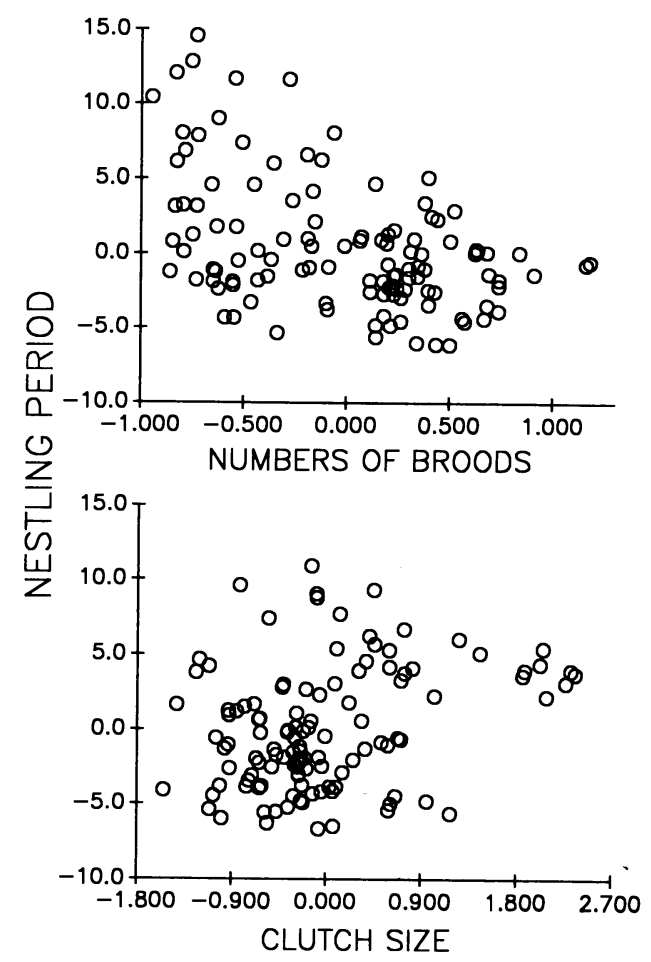

FIG. 5. Scattergrams of the standardized residuals (i.e., partial correlations) of nestling period (numbers of days nestlings remain in the nest) corrected for body fresh mass and latitude relative to numbers of broods (numbers of successful broods attempted per year) and clutch size (numbers of eggs per nest) both corrected for body mass in Passeriformes and 'Piciformes. Nestling period is related to numbers of broods and clutch size by the equation: Nestling period (d) $=15.439$ $+7.524 \log ($ fresh mass $[\mathrm{g}])-0.289$ Latitude (degrees North) +1.275 Clutch size (no. eggs) -3.403 Broods (numbers of successful attempts), $n=119$ species. 
TABLE 5. Data gathered from the literature on annual adult survival (percentage of individuals surviving between years), annual fecundity (product of numbers of broods and clutch size), numbers of broods (numbers of successful broods attempted per year), and clutch size of Passeriformes and Piciformes species that foraged in different sites and habitat types. Data represent means $\pm 1 \mathrm{SE}$.

\begin{tabular}{llccc}
\hline \hline Foraging site & Adult survival $(\%)$ & Annual fecundity & $\begin{array}{c}\text { Broods } \\
\text { (No./yr) }\end{array}$ & $\begin{array}{c}\text { Clutch size } \\
\text { (No. eggs per nest) }\end{array}$ \\
\hline Bark & \multicolumn{5}{c}{ Forest habitat $(n=73)$} \\
Ground & $0.626 \pm 0.045(8)^{*}$ & $5.69 \pm 0.674(13)$ & $1.15 \pm 0.067$ & $4.80 \pm 0.321$ \\
Canopy & $0.560 \pm 0.028(12)$ & $7.24 \pm 0.575(16)$ & $1.72 \pm 0.129$ & $4.32 \pm 0.229$ \\
Shrub & $0.566 \pm 0.027(16)$ & $6.82 \pm 0.580(23)$ & $1.41 \pm 0.087$ & $4.82 \pm 0.305$ \\
Aerial insects & $0.562 \pm 0.036(7)$ & $6.29 \pm 0.556(8)$ & $1.56 \pm 0.175$ & $4.12 \pm 0.139$ \\
& $0.460 \pm 0.020(8)$ & $5.70 \pm 0.695(12)$ & $1.42 \pm 0.149$ & $4.01 \pm 0.197$ \\
Ground & \multicolumn{2}{c}{ Shrub/grassland habitat $(n=50)$} \\
Shrub & $0.548 \pm 0.015(14)$ & $7.34 \pm 0.368(24)$ & $1.85 \pm 0.115$ & $4.00 \pm 0.133$ \\
Aerial insects & $0.537 \pm 0.192(14)$ & $8.28 \pm 0.467(21)$ & $2.10 \pm 0.107$ & $4.00 \pm 0.183$ \\
\hline
\end{tabular}

* Sample size $=$ number of species; sample sizes are the same for annual fecundity, numbers of broods, and clutch size.

with increased nest predation even among open-nesting birds, then ground-nesting species should have longer nestling periods than shrub nesters but similar nestling periods to canopy nesters within forest habitats, but not shrub/grasslands, based on Table 3. Analyses of the nestling period for Parulinae, which are mostly forestdwelling, vary among nest sites $(F=4.86, P=0.014)$ in the pattern predicted; ground-nesting species (10.6 $\pm 0.30 \mathrm{~d}$, mean $\pm 1 \mathrm{sE} ; n=16$ ) have longer nestling periods than shrub-nesting species $(9.3 \pm 0.29 \mathrm{~d}, n=$ 13) and similar periods to canopy nesters (10.3 \pm 0.48 $\mathrm{d}, n=6)$. In contrast, nestling periods for groundnesting species $(10.1 \pm 0.31 \mathrm{ds}, n=21)$ in the Emberizinae, a largely shrub/grassland group, do not differ ( $F=0.59, P=0.449$ ) from aboveground-nesting species $(9.7 \pm 0.43 \mathrm{~d}, n=14)$, although the trend is toward longer periods for ground-nesting species, exactly as found for nest predation in shrub/grassland (see Table 1). Thus, nestling period varies inversely with nest predation even within phylogenetically-related open-nesters.

\section{Survival and annual fecundity}

When body mass, latitude, and nest predation were examined as covariates of annual fecundity, only nest predation was significant (Table 1). Once variation in nest predation was controlled, annual fecundity still varied among nest sites and foraging sites (Table 1). Nest sites explained most variation in annual fecundity and accounted for $48.7 \%$ of the total variation that was explained; the variation in fecundity among nest sites is clear from Table 4. Foraging sites were significant only because aerial insectivores had lower fecundity than other groups (see Table 5); all other groups did not differ from each other $(P>0.05, \mathrm{GT} 2$ test $)$. Thus, if aerial insectivores were excluded from analyses, fecundity did not differ among the remaining four foraging sites $(F=0.73, P=0.537)$. When adult survival was included as a covariate, it was a strongly significant covariate and both body mass and latitude also were significant, while nest predation was insignificant (Ta- ble 1). In addition, nest sites did not explain any residual variation in annual fecundity once variation in survival was controlled, but foraging sites became highly significant in explaining the residual variation (Table 1).

Results were relatively similar when data were controlled for possible phylogenetic effects. When body mass and nest predation were included as covariates, nest sites again accounted for most variation in annual fecundity (Table 2). Foraging sites were not significant while migratory classification was significant at explaining variation in fecundity; fecundity was greater in short-distance migrants than in neotropical migrants or residents. In contrast, when adult survival was also included as a covariate, it again was a strong covariate and both nest predation and body mass explained additional variation in annual fecundity (Table 2). Once variation in these covariates was controlled, nest sites again did not explain any residual variation, but foraging sites did explain residual variation in annual fecundity (Table 2).

If survival is examined as the dependent variable, results are essentially the same as observed for fecundity. However, body mass was a significant covariate of annual adult survival $(F=8.82, P=0.005)$, while latitude $(F=0.26, P=0.615)$ and nest predation $(F$ $=2.52, P=0.119)$ were not significant covariates. Nest sites explained the majority of variation in adult survival $(F=10.25, P<0.0001)$ as evidenced by Table 4. Migratory classification was unimportant $(F=0.09$, $P=0.912$ ), contrary to arguments by previous investigators (e.g., Greenberg 1980, Dobson 1990). Yet, previous investigators did not control for nest site effects (see Martin 1993b). The lack of differences among migratory classifications within a nest site, but differences among nest sites are clear (Table 6). Survival also differed marginally among foraging sites $(F=2.63, P=$ 0.045 ), although the latter result was only because of the low survival of aerial insectivores (Table 5); exclusion of aerial insectivores caused foraging sites to no longer explain any residual variation in survival $(F$ 
TABLE 6. Annual adult survival (percentage of individuals surviving between years) among nest sites and migratory classifications. Data represent means $\pm 1 \mathrm{SE}$.

\begin{tabular}{|c|c|c|c|}
\hline \multirow[b]{2}{*}{ Nest site } & \multicolumn{3}{|c|}{ Migratory classification } \\
\hline & Residents & Short-distance & Neotropical migrants \\
\hline & & nual adult survival & \\
\hline Excavators & $0.67 \pm 0.028(5)^{*}$ & $0.66 \pm 0.044$ & \\
\hline Ground nesters & $\ldots$ & $0.56 \pm 0.028(6)$ & $0.62 \pm 0.016(10)$ \\
\hline Canopy nesters & $0.71 \pm 0.044(3)$ & 0.55 & $0.57 \pm 0.032(6)$ \\
\hline Shrub nesters & $0.53 \pm 0.029$ & $0.55 \pm 0.014(10)$ & $0.52 \pm 0.015(15)$ \\
\hline Non-excavators & $0.44 \pm 0.023(8)$ & $0.42 \pm 0.062$ & $0.43 \pm 0.013$ \\
\hline
\end{tabular}

* Sample size (number of species)

$=1.16, P=0.337)$. Thus, as found for fecundity, survival differed strongly among nest sites, but varied little among foraging sites.

When fecundity was included as a covariate, it was a strong covariate $(F=125.25, P<0.0001)$ and body mass was a significant covariate $(F=30.45, P<$ $0.0001)$, but neither latitude $(F=1.10, P=0.300)$ nor nest predation $(F=0.20, P=0.658)$ were significant covariates. Nest sites only explained a small amount of the residual variation $(F=3.37, P=0.016)$, whereas foraging site explained most of the residual variation $(F=13.34, P<0.0001)$.

The same patterns were found when phylogenetically-controlled data were examined: when fecundity was not included as a covariate, nest sites explained considerable variation $(F=17.80, P<0.0001)$ in survival and foraging sites explained a smaller amount $(F$ $=3.05, P=0.025)$ due to aerial insectivores. When fecundity was included as a covariate $(F=111.57, P$ $<0.0001)$, nest sites explained little residual variation $(F=2.49, P=0.056)$, whereas foraging sites accounted for most of the residual variation $(F=7.06$, $P<0.0001)$.

In short, both untransformed and phylogeneticallytransformed data were consistent in showing that foraging sites explained deviations (residual variation) from the relationship between fecundity and survival (i.e., whenever either was included as a covariate for the other). In contrast, nest sites explained most of the variation in each of fecundity and survival taken alone, and fecundity and survival varied inversely with each other among nest sites (Table 4). Thus, the main axis of variation between fecundity and survival was described by nest sites, and deviations from this axis were largely accounted for by foraging sites.

In Whitcomb data, similar patterns of differences were apparent in annual fecundity $(F=7.9, P<$ $0.0001)$ and longevity $(F=3.2, P=0.022)$ among nest sites (Table 4). In these data, there was also a difference in both annual fecundity $(F=9.7, P<$ $0.0001)$ and longevity $(F=6.2, P=0.004)$ among migrant classifications: short-distance migrants had higher fecundity and shorter longevity than residents or neotropical migrants. The congruence of patterns among nest sites in survival (based on the literature data set) and longevity (based on the Whitcomb data

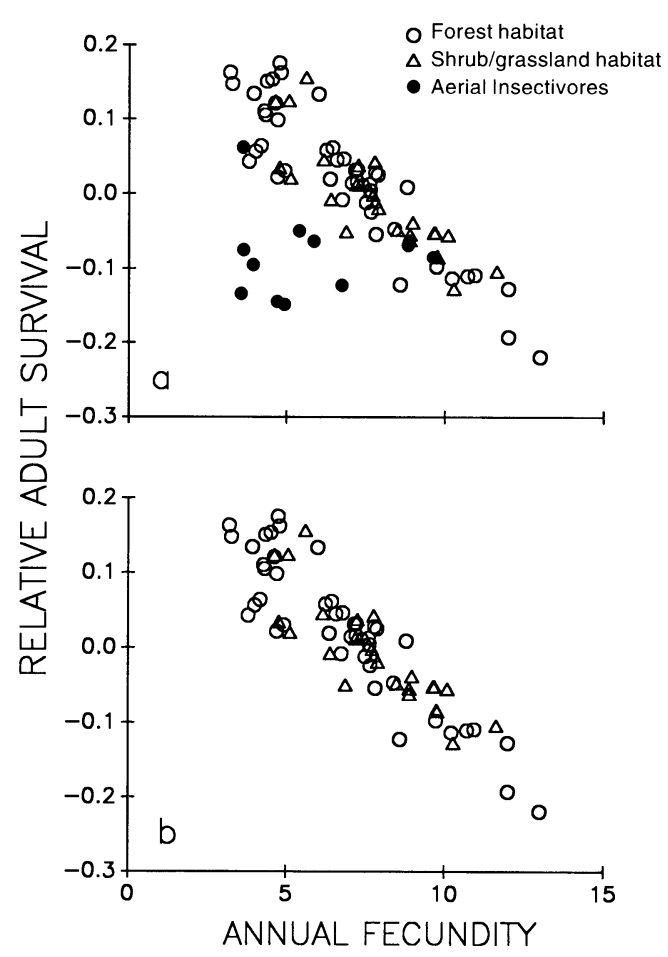

FIG. 6. Scattergrams of the standardized residuals (i.e., partial correlations) of annual adult survival (percentage of individuals that survive between years) corrected for body fresh mass (see Fig. 7) relative to annual fecundity (clutch size $\times$ number of broods) in Passeriformes and Piciformes. Open circles represent species that occupy forest habitats, open triangles represent species that occupy shrub or grassland habitats and solid circles represent species that feed on flying insects. (a) Aerial insectivores are included. Corrected adult survival is related to annual fecundity among habitats by the following equations: All habitats: Survival $=0.617$ $+0.082 \log ($ fresh mass $[\mathrm{g}])-0.026$ Fecundity (eggs), $n=$ 83 species. Forest: Survival $=0.630+0.081 \log ($ fresh mass [g]) -0.028 Fecundity (eggs), $n=52$ species. Shrub/grassland: Survival $=0.597+0.068 \log ($ fresh mass $[\mathrm{g}])-0.021$ Fecundity (eggs), $n=31$ species. (b) Aerial insectivores are not included. All habitats: Survival $=0.726+0.067 \log ($ fresh mass $[\mathrm{g}])-0.035$ Fecundity (eggs), $n=72$ species. Forest: Survival $=0.731+0.070 \log ($ fresh mass $[\mathrm{g}])-0.037 \mathrm{Fe}-$ cundity (eggs), $n=45$ species. Shrub/grassland: Survival = $0.723+0.045 \log ($ fresh mass $[\mathrm{g}])-0.031$ Fecundity (eggs), $n=27$ species. 


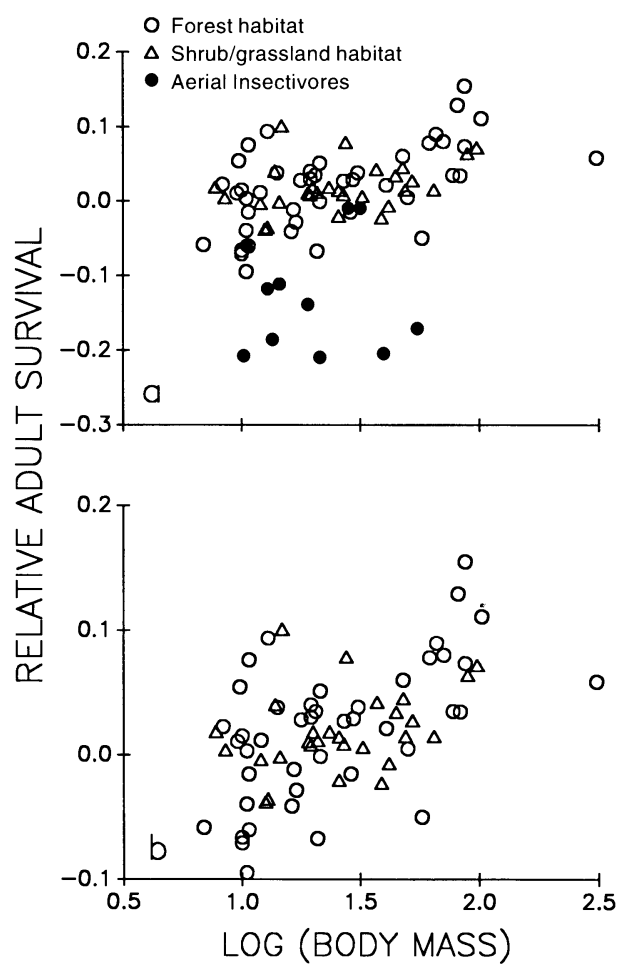

FIG. 7. Scattergrams of the standardized residuals (i.e., partial correlations) of annual adult survival (percentage of individuals that survive between years) corrected for annual fecundity relative to body fresh mass ( $\mathrm{g}$ ) in Passeriformes and Piciformes. Adult survival is related to body fresh mass by the following equations: (a) aerial insectivores included: Survival $=0.617+0.082 \log ($ fresh mass $[\mathrm{g}])-0.026 \mathrm{Fe}$ cundity (eggs), $n=83$ species, and (b) aerial insectivores not included: Survival $=0.726+0.067 \log ($ fresh mass $[\mathrm{g}])$ -0.035 Fecundity (eggs), $n=72$ species.

set) is somewhat surprising because these two measures tend to covary poorly (Krementz et al. 1989). Survival estimates were available for 27 species in the Whitcomb data. Survival and longevity were not correlated $(r=0.135, P=0.502)$ for these species, although the two aerial insectivores in this sample were outliers and exclusion of them yielded a better correlation $(r=$ $0.393, P=0.052$ ). Nonetheless, the relationship between survival and longevity is weak and the congruence of patterns for both survival and longevity among nest types suggests that differences in fecundity and survival-longevity among nest types are robust.

Fecundity and survival were strong covariates of each other, reflecting the strong inverse correlation between them $\left(r_{p}=-0.664, P<0.0001 ;\right.$ Fig. 6a) when variation related to body mass was controlled; survival was clearly related to body mass $\left(r_{p}=0.392, P=\right.$ 0.0003 ; Fig. 7). The slope of the relationship between survival and log-transformed body mass (slope \pm SE $=0.082 \pm 0.022)$ is not statistically different from those reported for European, British, and Australian passerines (Saether 1989, Dobson 1990, Yom-Tov et al. 1992). Moreover, the relationship between adult sur- vival and fecundity (Fig. 6) is robust as it was strong in both shrub/grassland $\left(r_{p}=-0.590, P=0.0006\right)$ and forest $\left(r_{p}=-0.671, P<0.0001\right)$.

Aerial insectivores were outliers for both survival/ fecundity (Fig. 6a) and survival/body mass (Fig. 7) relationships. When they were excluded, the relationships between relative adult survival and both fecundity $\left(r_{p}=-0.914, P<0.0001\right.$; Fig. $\left.6 \mathrm{~b}\right)$ and body mass $\left(r_{p}=0.545, P<0.0001\right)$ were much stronger. Exclusion of aerial insectivores also improved the relationship between fecundity and relative adult survival in both shrub/grassland $\left(r_{p}=-0.885, P<0.0001\right)$ and forest $\left(r_{p}=-0.919, P<0.0001\right)$. Because aerial insectivores were outliers, the slope of the relationship between survival and body mass is probably more accurately reflected by the value obtained when aerial insectivores were excluded $(0.067 \pm 0.012)$. Indeed, the slope of the relationship between body mass and survival when phylogeny was controlled $(0.061 \pm$ $0.029)$ is similar to the latter slope, and the relationship between fecundity and survival remained strong $\left(r_{p}=\right.$ $-0.831, P<0.0001$; Fig. 8 ). Both survival/body mass slopes are nearly identical to the one observed for Australian passerines $(0.065$, reported by Yom-Tov et al. 1992). Thus, survival data examined here show relationships similar to data from other geographic regions; these relationships are still apparent when possible phylogenetic effects are controlled.

Annual fecundity is determined by both clutch size and numbers of broods. Previous attention has focused on clutch size as the primary determinant of reproductive effort and survival (see Martin 1987, Saether 1988; but see Dobson 1990). However, annual fecundity actually was more strongly correlated with numbers of broods $\left(r_{p}=0.700, P<0.0001\right)$ with a higher

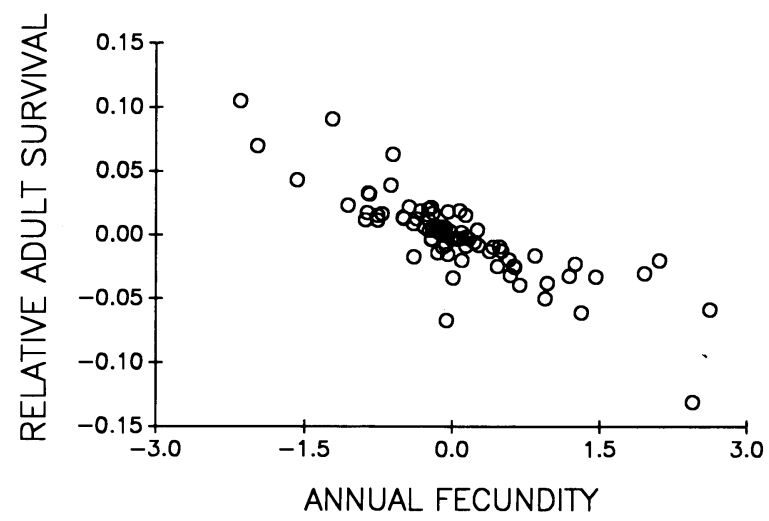

FIG. 8. Scattergram of the standardized residuals (i.e., partial correlation) of annual adult survival (percentage of individuals that survive between years) corrected for body fresh mass relative to annual fecundity (clutch size $\times$ number of broods), all of which are corrected for phylogeny using independent contrasts. Corrected survival is related to annual fecundity by the equation: Survival $=0.061 \log$ (fresh mass) -0.033 Fecundity, $n=81$ independent contrasts. 
TABLE 7. Partial correlations $\left(r_{p}\right)$ of annual adult survival (percentage of individuals surviving between years) with clutch size vs. numbers of broods analyzed separately, but correcting for body fresh mass in both cases. Standardized regression coefficients (beta) of annual adult survival with clutch size and numbers of broods analyzed simultaneously and also correcting for fresh body mass.

\begin{tabular}{|c|c|c|c|}
\hline & $r_{p}$ & $P$ & beta \\
\hline \multicolumn{4}{|c|}{ All habitats $(n=83$ species $)$} \\
\hline $\begin{array}{l}\text { Numbers of broods } \\
\text { Clutch size }\end{array}$ & $\begin{array}{l}-0.461 \\
-0.263\end{array}$ & $\begin{array}{l}0.0000 \\
0.0175\end{array}$ & $\begin{array}{l}-0.581 \\
-0.441\end{array}$ \\
\hline \multicolumn{4}{|c|}{$\begin{array}{l}\text { All habitats with phylogeny controlled } \\
(n=80 \text { independent contrasts })\end{array}$} \\
\hline $\begin{array}{l}\text { Numbers of broods } \\
\text { Clutch size }\end{array}$ & $\begin{array}{l}-0.618 \\
-0.210\end{array}$ & $\begin{array}{l}0.0000 \\
0.0617\end{array}$ & $\begin{array}{l}-0.858 \\
-0.580\end{array}$ \\
\hline \multicolumn{4}{|c|}{ Excluding aerial insectivores $(n=72)$} \\
\hline $\begin{array}{l}\text { Numbers of broods } \\
\text { Clutch size }\end{array}$ & $\begin{array}{l}-0.650 \\
-0.316\end{array}$ & $\begin{array}{l}0.0000 \\
0.0072\end{array}$ & $\begin{array}{l}-0.865 \\
-0.644\end{array}$ \\
\hline \multicolumn{4}{|c|}{$\begin{array}{l}\text { Excluding aerial insectivores with phylogeny controlled } \\
\qquad(n=69)\end{array}$} \\
\hline $\begin{array}{l}\text { Numbers of broods } \\
\text { Clutch size }\end{array}$ & $\begin{array}{l}-0.680 \\
-0.164\end{array}$ & $\begin{array}{l}0.0000 \\
0.177\end{array}$ & $\begin{array}{l}-0.906 \\
-0.561\end{array}$ \\
\hline
\end{tabular}

standardized regression coefficient (beta $=0.854$ ) than with clutch size $\left(r_{p}=0.478, P<0.0001\right.$; beta $\left.=0.713\right)$. As a result, adult survival also was more highly correlated and had a higher standardized regression coefficient with numbers of broods than with clutch size, even when phylogeny was controlled (Table 7). However, note that the correlations of adult survival with numbers of broods and clutch size were lower than the correlation with annual fecundity, showing that each component contributes independently to variation in adult survival.

Re-analysis of the Whitcomb data yielded similar results. Longevity corrected for body mass was negatively correlated with annual fecundity $\left(r_{p}=-0.561\right.$, $P<0.0001, n=57$ ). Of the two components of fecundity, number of broods was much more closely related to longevity $\left(r_{p}=-0.538, P<0.0001\right)$ than was clutch size $\left(r_{p}=-0.303, P=0.024\right)$, indicating that number of broods is the more important influence on the relationship between annual fecundity and longevity. Indeed, annual fecundity, corrected for body mass, was more strongly correlated $\left(r_{p}=0.888, P<0.0001\right)$ and had a higher standardized regression slope (beta $=0.975)$ with number of broods than with clutch size $\left(r_{p}=0.228, P=0.091\right.$; beta $\left.=0.441\right)$.

\section{Discussion}

\section{The fecundity-survival relationship}

Adult survival was inversely related to clutch size when examined across a diverse taxonomy of European birds, but not when restricted to passerines (see Saether 1988). Results provided here show that adult survival was inversely related to clutch size for North American passerines. However, adult survival was even more strongly related to annual fecundity (Fig. 6) and num- bers of broods. The inverse correlation between fecundity measures and adult survival may be either evolutionary or a direct result of density-dependent processes (Bennett and Harvey 1988, Saether 1988). Density-dependence is commonly invoked as an explanation because fecundity must balance mortality in stable populations and, thus, variation in adult mortality is thought to follow from fecundity influencing density-dependent costs (Sutherland et al. 1986, Bennett and Harvey 1988, Gustafsson and Sutherland 1988, Saether 1988, Linden and Møller 1989, Sutherland 1989). Yet, evidence suggests that a cost of reproduction does commonly exist (see Nur 1988, 1990). In contrast, evidence supporting density-dependence as the cause of the inverse correlation between fecundity and survival is more tenuous. Increased density can cause reductions in both adult survival and clutch size (e.g., Perrins 1965, Ekman 1984, Arcese and Smith 1988, Dhondt et al. 1992) and such density-dependent effects cause a positive correlation between fecundity and adult survival rather than the negative one observed. Moreover, there is no evidence that densitydependent effects on adult mortality are greater in species with greater fecundity. Indeed, a species may have a stable population because territoriality (density-dependence) causes excess young produced in a good habitat to disperse to lower quality habitats where reproductive success is insufficient to maintain the local population, such that metapopulation stability is attained by differential reproductive success and dispersal and not by effects on evolved life history traits such as fecundity and survival (e.g., see Dhondt et al. 1990, Blondel et al. 1993).

The more critical question of interest here is: What are the causes of variation in fecundity and survival among species? Of course, interspecific comparisons cannot determine causation, but the correlations can potentially provide insight into causes and may highlight potential evolutionary influences that may not be uncovered by intraspecific tests (see sections entitled Food effects and Nest predation and nest sites).

The relationship between fecundity and adult survival could be driven by either trait (Williams 1966a, $b$, Charnov and Krebs 1974, Hirshfield and Tinkle 1975, Law 1979, Michod 1979, Bell and Koufopanou 1986). Mortality is often emphasized as the driving force (e.g., Law 1979, Michod 1979, Curio 1989, Crowl and Covich 1990, Reznick et al. 1990). Evidence argues against adult mortality as the causal pathway for the taxa examined here; ecological sources of adult mortality (e.g., predation) are not known to differ among the ecological conditions (e.g., nest sites) in which life history traits vary. One possible exception is that cavity-nesting birds might be predicted to suffer higher mortality than open-nesting birds due to residency differences; residents have been argued to suffer higher winter mortality than migrants and a greater proportion of cavity-nesting species are residents than for open 


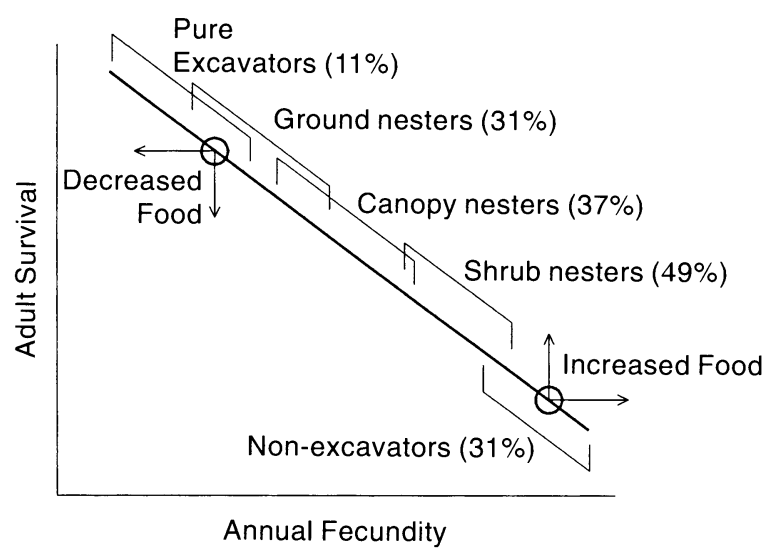

FIG. 9. Schematic summary of the function between annual fecundity and adult survival and the contribution of ecological factors to variation along the function. Points (i.e., different species) along the function represent different fecundity-survival schedules, leading to equivalent fitnesses. Differences among species along the main axis of the function are primarily explained by nest sites (see Table 4 ) and correlated with nest predation rates (numbers in parentheses are nest predation rates; see Table 3). Effects of food may be primarily through deviations from the function, whereas points along the function potentially represent similar levels of food limitation.

nesters (Haartman 1957, O'Connor 1985). Yet, survival did not differ among migratory classifications within a nest site (Table 6). Moreover, cavity nesters include species with the highest (excavators) and lowest (nonexcavators) adult survival rates (Fig. 9). Thus, adult survival differences among nest sites are not easily explained by extrinsic sources of mortality (e.g., predation or winter mortality). In contrast, variation in fecundity is strongly associated with ecological factors, suggesting that variation in adult survival may follow from fecundity varying in response to ecological factors (see next section on Food effects, also Ekman and Askenmo 1986).

Food effects.-Food has long been considered the primary influence on fecundity, which is thought to subsequently affect adult survival through the cost of reproduction (Lack 1948, 1968, Williams 1966a, b, Charnov and Krebs 1974, Murphy and Haukioja 1986, Martin 1987, Nur 1990). Under the cost of reproduction hypothesis, increased fecundity can reduce survival either through increased predation or pathogens associated with the reproductive effort, or from energy depletion (food limitation; Williams 1966a, $b$, Charnov and Krebs 1974, Reznick 1985, Bell and Koufopanou 1986). Many intraspecific studies show that energy costs of reproduction commonly affect future fecundity and sometimes survival in birds (reviewed in Martin 1987, Nur 1988, 1990, Linden and Møller 1989, Roff 1992, Stearns 1992).

Even if food limitation is the cause of the trade-off between fecundity and survival, it does not necessarily mean that food explains the variation among species along the fecundity-survival function. In fact, different points on the fecundity-survival line may simply represent similar levels of energy limitation but different tactics for partitioning this limited energy between parents and young (also see Winkler 1987, Gustafsson and Sutherland 1988); species at the upper end may put less energy into young and save more energy for their own survival and the converse at the lower end. Indeed, species with very large clutches and those with very small clutches both show negative effects of brood manipulations, indicating that food limitation exists at all fecundity levels (reviewed in Martin 1987). Yet, a negative relationship between fecundity and survival may actually indicate that food is not very important to variation in fecundity and survival (Fig. 1); bird species with access to more food should be able to raise more young with similar or even enhanced adult survival, leading to a positive correlation between fecundity and survival when food is important. Such results have been observed intraspecifically under natural conditions (e.g., Hogstedt 1980, 1981, Smith 1981, Pettifor et al. 1988, Blondel et al. 1992, 1993) and with experimental manipulation of food (reviewed in Martin 1987, Brittingham and Temple 1988, but see Arcese and Smith 1988). Such relationships should cause food effects to be minor and expressed as deviations when an inverse survival-fecundity function exists (Fig. 1). These predictions were strongly supported by the data showing that fecundity and survival did not differ among foraging sites, with exception of aerial insectivores, but that foraging site explained a significant amount of the residual variation in annual fecundity when survival effects were removed (i.e., deviations from the survival-fecundity function). The potentially minor role of food in influencing variation in fecundity and survival among species can be seen when comparing coexisting species; e.g., ground-nesting warblers (Parulinae) that feed on foliage-clinging arthropods in the canopy have larger clutches than coexisting warblers that nest above the ground and also feed on canopy, foliage-clinging arthropods (Martin 1988c, Martin and Li 1992). Plus, coexisting cavity-nesting chickadees (Parus spp.) and nuthatches (Sitta spp.) that also feed on canopy arthropods have even larger clutches (Martin and $\mathrm{Li}$ 1992). Of course, I do not imply that food has no importance, but rather that its importance in the evolution of interspecific variation in fecundity and survival may be much less than traditionally accepted.

Aerial insectivores provide an example of food effects; aerial insectivores commonly experience food shortages and nestling starvation (Lack and Lack 1951, Davies 1977, Bryant and Hails 1983, Murphy 1983b, 1989) and therefore, are expected to fall as deviations below the fecundity/survival function (Fig. 1). Indeed, aerial insectivores were low outliers (Fig. 6). Moreover, examination of data for European passerines (Saether 1987, Dobson 1990) also shows that Hirundinidae (aerial insectivores) had low survival rates for their size 
and fecundity. Yet, species below the line should have decreasing populations unless compensated by increased nesting or juvenile survival (Sutherland et al. 1986, Gustafsson and Sutherland 1988). Reduced fecundity and survival caused by unpredictable food (aerial insects) then might favor increased nest defense to reduce nest predation or extended parental care to increase survival of juveniles; such behaviors have been observed for flycatchers (Murphy 1983c, Martin $1992 b)$. Thus, aerial insectivores provide an example of the potential effects of food on life history evolution, but even here nest sites are still influential; aerial insectivores that use cavities or enclosed nests have greater fecundities and lower survival than those in more exposed nest sites (Appendix 1).

Note that this discussion centers on causes of variation among species. Tests of life history evolution in birds have largely focused on phenotypic rather than genetic responses. Organisms may exhibit strong phenotypic plasticity in response to environmental factors that are variable but predictable (Levins 1963, Clark and Harvell 1992, Gabriel and Lynch 1992). Many types of food are variable but predictable, once sampled, and birds show life history plasticity in response to such food (Martin 1987). Yet, such phenotypic responses do not necessarily reflect genetic correlations (Price and Liou 1989) and thus phenotypic responses to food can occur even when food is not important to evolution of the life history traits; i.e., availability of food may differ among individuals causing intraspecific variation in life history traits, but if food abundance does not differ predictably among species, then food is not the cause of evolved interspecific differences. In contrast, ecological factors that are variable but unpredictable may not favor phenotypic plasticity among individuals within a population, but may still influence evolution of differences among populations or species (see Harvell 1986, Lively 1986, Etges 1989, Clark and Harvell 1992, Gavrilets and Scheiner 1993). For example, nest predation is unpredictable to individuals within a population (any nest can get depredated), but risk of predation can differ predictably among populations, potentially favoring life history differences among individuals between populations, but not within populations. Thus, studies that ignore traits or ecological factors that do not show phenotypic plasticity within populations can miss potentially important evolutionary patterns and processes. For example, clutch size may vary among species but not within some species (e.g., Dhondt et al. 1990, Brawn 1991, Rowley et al. 1991). The absence of intraspecific variation does not mean that the trait did not evolve in response to ecological factors and, in fact, the variation among species indicates action of some evolutionary process, even if it is genetic drift. Similarly, reproductive effort may evolve to differ among species, but the reproductive effort evolved by a species may be held relatively constant by parents (no phenotypic plasticity) even in the face of changing resources (e.g., see Wilbur 1977, Sinervo and Licht 1991, Boggs and Ross 1993). If reproductive effort is held constant, then: (1) fecundity (clutch size or numbers of broods) and possibly adult survival should increase when more food is available because more young can be raised for the same or reduced effort, and (2) experimental increases in energy demands (e.g., brood size) should be translated into reduced survival and fitness of young rather than of parents in most cases. Both predictions are widely observed (see reviews in Martin 1987, Linden and Møller 1989). In short, food may cause phenotypic variation in fecundity and survival, but food may still be of minor importance to the evolution of fecundity and reproductive effort, which instead may be more strongly influenced by ecological factors or evolutionary processes that may not cause phenotypic plasticity within populations.

Nest predation and nest sites.-Nest predation related to nest site use is an environmental factor that potentially is unpredictable and may not favor phenotypic plasticity, but can differ among species and may favor interspecific variation (Martin 1988c, Kulesza 1990, Sieving 1992). Annual fecundity, numbers of broods, clutch size and adult survival vary predictably among nest sites (Table 4). Cavity-nesting birds, which historically have been treated as a single group, define the two ends of the fecundity-survival function (Fig. 9). Actually, some excavators fall in the middle range because they mix excavating and non-excavating habits and have intermediate fecundities (Martin $1993 c$ ). Pure excavators (those that always excavate) have an annual fecundity of about 4.80 eggs (Martin $1993 c$ ) causing them to fall at the top (see Fig. 9). The variation in fecundity and clutch size among nest sites occurs in the same rank order as nest predation except for non-excavators (see Fig. 9). As a result, nest predation was significantly correlated with both reproductive traits, particularly when non-excavators were excluded from the analyses. Nest predation and nest site together explained $>50-60 \%$ of the variation in clutch size and annual fecundity. It is not surprising that nest predation does not explain a larger amount of the variation in reproductive traits. Nest predation estimates are influenced by local perturbations at study sites (e.g., habitat fragmentation; Wilcove 1985, Andren and Angelstam 1988, Small and Hunter 1988, Yahner and Scott 1988) and, thus, may not reflect rates over evolutionary time for some species (Martin 1993a). However, average rates among nest sites appear to reflect evolutionary differences as they vary in the same order as traits (e.g., duration of the nestling period) that are known to vary with nest predation (Case 1978, Martin and Li 1992). Consequently, local effects on estimated predation rates increase statistical noise and reduce the overall correlation between nest predation and reproductive traits. Nonetheless, nest sites and associated nest predation accounts for the 
majority of variation along the fecundity/survival function (Tables 1-5 and Fig. 9).

Nest predation may act together with food limitation to influence covariation of life history traits (see Martin $1992 b)$. Higher nest predation rates are associated with a shorter nesting cycle (Fig. 4), reducing the vulnerable period and allowing more attempts per season (Figs. 2 and 5), providing broad support for relationships suggested previously (see Lack 1948, 1954, 1968, Case 1978, Ricklefs 1984, Westmoreland et al. 1986, Zaias and Breitwisch 1989, Major 1991, Rowley et al. 1991, Sieving 1992). In contrast, Lack (1948, 1968) argued that longer nestling periods under reduced predation allow larger clutch sizes, but clutch size was not correlated with nestling period when phylogenetic effects were controlled, providing little support for this hypothesis (also see Ricklefs 1968). Instead, increased nest predation may favor increased iteroparity to spread risk (bet-hedging; Slatkin 1974, Bulmer 1984) which may be manifested as reduced clutch size to save energy for renesting attempts following failure, or more broods following success (Foster 1974, Slagsvold 1982, 1984, Linden 1988). Number of broods increase with food availability (Bromssen and Jansson 1980, Simons and Martin 1990, Rodenhouse and Holmes 1992), suggesting that energy limits the number of broods and providing a basis for an energy trade-off. Indeed, clutch size decreased with increased numbers of broods (Fig. 3). Ultimately, clutch size may not be the primary life history trait optimized by selection; instead, numbers of broods may be more pivotal, as reflected by its stronger correlations with nest predation and nestling period as well as with both annual fecundity and annual survival (also see Bryant 1979, Bennett and Harvey 1988, Dobson 1990).

Non-excavators were a consistent outlier in the nest predation relationships, with larger clutch sizes and annual fecundity for their nest predation rates relative to the other four nest sites (Fig. 9); exclusion of nonexcavators increased correlations between nest predation vs. clutch sizes, numbers of broods, and annual fecundity. This result suggests that nest predation contributes very little to the large clutch sizes of nonexcavators, in contrast to conventional thinking (e.g., Lack 1948, 1954, 1968, Lima 1987). The large clutch size of non-excavators may be explained by a new hypothesis that suggests that their dependence on existing holes for nesting, which are limited in availability, can favor increased reproductive effort when a nest site is obtained (see Martin and Li 1992, Martin 1993c). Thus, nest sites may play a role in influencing fecundity traits independent of predation, although predation may shape choice of nest sites evolutionarily (Collias and Collias 1984, Martin 1988b, d).

In summary, food may influence trade-offs among traits such as clutch size vs. numbers of broods and survival vs. fecundity, but existence of such trade-offs does not necessarily mean that food is an important evolutionary influence on variation in these life history traits among species. The results support the prediction that food plays a minor role in the evolution of interspecific variation in life history traits because food effects are expressed as deviations from the inverse relationship between fecundity and survival. Variation in these traits, plus nestling period, are much more strongly correlated with variation in nest sites and nest predation than with foraging sites. Several relationships with nest predation (Figs. 2-5) have been previously suggested and the results simply confirm them. Yet, the broad nature of these relationships is unappreciated, and this broad nature forms the basis for nest predation and nest sites to act as potentially strong organizing influences on the evolution of life histories (e.g., Fig. 9).

\section{Migration tendencies and habitat types}

Migration habits also contributed to variation in life history traits. Neotropical migrants are commonly argued to have fewer broods than residents and shortdistance migrants (Whitcomb et al. 1981), partly because neotropical migrants may have a shorter nesting season than residents and short-distance migrants (also see Murray 1985). Yet, O'Connor (1990) found that, with respect to British birds, residents had fewer broods than did migrants. However, effects of nest site were not considered, although numbers of broods clearly differed among nest sites (Table 4) and nest site is not equally represented among migratory classifications; many resident species are cavity nesters. Moreover, migratory tendencies are confounded with habitat differences; short-distance migrants represent a greater proportion of species in shrub/grassland habitats than in forests. As a result, differences in numbers of broods within nest sites may be related to migratory classifications or habitat types. Analyses of the data here indicate a tendency for short-distance migrants to have more broods, but the greater numbers of broods of short-distance migrants also may be a function of their use of early successional habitat, although the analyses are restricted by small sample sizes when divided among nest sites, habitat types, and migratory classifications. Nonetheless, the fewer number of broods for residents vs. short-distance migrants and the similar number of broods between residents vs. neotropical migrants, within nest sites, argues strongly against timing of breeding as a major influence on variation in numbers of broods among species; residents generally start breeding the earliest of the groups.

Migratory classification did not influence annual fecundity, except when phylogeny was controlled (Tables 1 and 2); when phylogeny was controlled, residents and short-distance migrants had higher annual fecundity than neotropical migrants within a nest site and habitat type. Similar results were indicated by the Whitcomb data set. Yet, adult survival did not differ among migratory classifications within a nest site (Table 6 , 
also see Martin 1993b). Given the inverse association of fecundity and survival (Fig. 6), the lack of correspondence of these two results is difficult to explain. Part of the problem lies in small sample sizes: survival and fecundity data were acquired for only 83 species, and when these are divided among five nest sites and three migratory classifications, the sample size possibly becomes too fragmented to detect differences. More rigorous estimates of adult survival for a wider array of species are needed to allow clearer analysis of such issues.

In sum, a majority of interspecific variation along the fecundity-survival function is related to variation in nest sites and nest predation rather than foraging sites. Food limitation appears to be common and may lay the foundation for the inverse relationship, but the effect of food on variation in traits appears to be manifested through deviations from the function rather than variation along the fecundity-survival function. Habitat type and migratory classification also appear to influence variation in fecundity and possibly survival, but further studies and larger sample sizes are needed. Renesting frequency and numbers of broods seem to be key life history traits influencing annual fecundity and adult survival, but these traits are poorly studied; in most cases, anecdotal data are provided for numbers of broods rather than detailed studies of population means and variance within and among years (see Holmes et al. 1992). Intensive color-banding studies that allow examination of annual fecundity and adult survival are needed to improve our understanding of demographic differences among nest sites, habitat types, and migratory classifications. Finally, studies of nest predation in both pristine and disturbed habitat conditions are needed to better determine potential historical rates (pristine conditions) and to determine the demographic consequences of elevated rates (disturbed conditions) on not only reduced nest success, but also on renesting frequency, numbers of broods, and the consequences for adult survival.

\section{ACKNOWLEDGMENTS}

I thank J. Brawn, W. J. Etges, C. Paine, M. T. Murphy, T. Slagsvold, and an anonymous reviewer for helpful comments. D. Promislow and E. Martins provided much patience and advice on performing statistical methods for controlling phylogenetic effects. I thank my graduate students (D. Barber, C. Ghalambor, L. Garner, and S. Garner) for help in constructing the phylogeny and for stimulating discussion. This work was supported by NSF grant BSR-9006320.

\section{Literature Cited}

Albano, D. J. 1992. Nesting mortality of Carolina Chickadees breeding in natural cavities. Condor 94:371-382.

Allen, R. W., and M. M. Nice. 1957. A study of the breeding biology of the Purple Martin (Progne subis). American Midland Naturalist 47:606-665.

Anderson, A. H., and A. Anderson. 1973. The cactus wren. University of Arizona Press, Tucson, Arizona, USA.

Andren, H., and P. Angelstam. 1988. Elevated predation rates as an edge effect in habitat islands: experimental evidence. Ecology 69:544-547.
Arcese, P., and J. N. M. Smith. 1988. Effects of population density and supplemental food on reproduction in Song Sparrows. Journal of Animal Ecology 57:119-136.

Avise, J. C., J. C. Patton, and C. F. Aquadro. 1980a. Evolutionary genetics of birds. I. Relationships among North American thrushes and allies. Auk 97:135-147.

Avise, J. C., J. C. Patton, and C. F. Aquadro. 1980b. Evolutionary genetics of birds. II. Conservative protein evolution in North American sparrows and relatives. Systematic Zoology 29:323-334.

Avise, J. C., J. C. Patton, and C. F. Aquadro. 1980c. Evolutionary genetics of birds. III. Comparative molecular evolution in New World warblers and rodents. Journal of Heredity 71:303-310.

Balda, R. P., and G. C. Bateman. 1972. The breeding biology of the Pinon Jay. Living Bird 11:5-42.

Barber, D. R. 1993. Effects of alternate host densities on Brown-headed Cowbird parasitism rates in Black-capped Vireos. Thesis. University of Arkansas, Fayetteville, Arkañsas, U'SA.

Barlow, J. C. 1962. Natural history of the Bell's Vireo, Vireo bellii Audubon. University of Kansas Publications of $\mathrm{Mu}$ seum of Natural History 12:241-296.

Baylor, L. M., and N. R. Whitney, Jr. 1976. Survival rates of returned White-winged Juncos. Bird-Banding 47:301305.

Bedard, J., and G. LaPointe. 1984. Banding returns, arrival times, and site fidelity in the Savannah Sparrow. Wilson Bulletin 96:196-205.

Bell, G., and V. Koufopanou. 1986. The cost of reproduction. Oxford Surveys in Evolutionary Biology 3:83-131.

Bennett, P. M., and P. H. Harvey. 1988. How fecundity balances mortality in birds. Nature 333:216.

Berger, A. J. 1967. Traill's Flycatcher in Washtenaw County, Michigan. Jack-Pine Warbler 45:117-123.

Bermingham, E., S. Rohwer, S. Freeman, and C. Wood. 1992. Vicariance biogeography in the Pleistocene and speciation in North American wood warblers: a test of Mengel's model. Proceedings of the National Academy of Sciences, USA 89:6624-6628.

Berrigan, D., A. Purvis, P. H. Harvey, and E. L. Charnov. 1993. Phylogenetic contrasts and the evolution of mammalian life histories. Evolutionary Ecology 7:270-278.

Best, L. B. 1978. Field Sparrow reproductive success and nesting ecology. Auk 95:9-22.

Best, L. B., and D. F. Stauffer. 1980. Factors affecting nesting success in riparian bird communities. Condor 82:149-158.

Blancher, P. J., and R. J. Robertson. 1985. Site consistency in kingbird breeding performance: implications for site fidelity. Journal of Animal Ecology 54:1017-1027.

Bledsoe, A. H. 1988. Nuclear DNA evolution and phylogeny of the New World nine-primaried oscines. Auk 105:504515.

Blondel, J., P. C. Dias, M. Maistre, and P. Perret. 1993. Habitat heterogeneity and life history variation of Mediterranean Blue Tits (Parus caeruleus). Auk 110:511-520.

Blondel, J., R. Pradel, and J.-D. Lebreton. 1992. Low fecundity insular Blue Tits do not survive better as adults than high fecundity mainland ones. Journal of Animal Ecology 61:205-213.

Boggs, C. L., and C. L. Ross. 1993. The effect of adult food limitation on life history traits in Speyeria mormonia (Lepidoptera: Nymphalidae). Ecology 74:433-441.

Brawn, J. D. 1991. Environmental effects on variation and covariation in reproductive traits of Western Bluebirds Oecologia 86: 193-201.

Bray, O. E., A. M. Gammell, and D. R. Anderson. 1979. Survival of Yellow-headed Blackbirds banded in North Dakota. Bird-Banding 50:252-255. 
Brewer, R. 1963. Ecological and reproductive relationships of Black-capped and Carolina Chickadees. Auk 80:9-47.

Briskie, J. V., and S. G. Sealy. 1989. Nest-failure and the evolution of hatching asynchrony in the Least Flycatcher. Journal of Animal Ecology 58:653-665.

Brittingham, M. C., and S. A. Temple. 1988. Impacts of supplemental feeding on survival rates of Black-capped Chickadees. Ecology 69:581-589.

Bromssen, A. von, and C. Jansson. 1980. Effects of food addition to Willow Tit Parus montanus and Crested Tit $P$. cristatus at the time of breeding. Ornis Scandinavica 11: 173-178.

Brooks, D. R., and D. A. McLennan. 1991. Phylogeny, ecology, and behavior: a research program in comparative biology. University of Chicago Press, Chicago, Illinois, USA.

Brown, C. R., and M. B. Brown. 1992. Ectoparasitism as a cause of natal dispersal in Cliff Swallows. Ecology 73: 1718-1723.

Bryant, D. M. 1979. Reproductive costs in the House Martin (Delichon urbica). Journal of Animal Ecology 48:655-675.

Bryant, D. M., and C. J. Hails. 1983. Energetics of growth in House Martins (Delichon urbica). Journal of Zoology 189:275-304.

Bull, E. L., and E. C. Meslow. 1988. Breeding biology of the Pileated Woodpecker-management implications. USDA Forest Service PNW-RN-474:1-8.

Bulmer, M. G. 1984. Risk avoidance and nesting strategies. Journal of Theoretical Biology 106:529-535.

Burns, J. T. 1982. Nests, territories, and reproduction of Sedge Wrens (Cistothorus platensis). Wilson Bulletin 94: 338-349.

Butler, R. W., N. A. M. Verbeek, and H. Richardson. 1984. The breeding biology of the Northwestern Crow. Wilson Bulletin 96:408-418.

Caccamise, D. F. 1977. Nesting success and nest site characteristics in the Red-winged Blackbird. Wilson Bulletin 89:396-403.

Calow, P., and A. S. Woolhead. 1977. The relationship between ration, reproductive effort and age-specific mortality in the evolution of life history strategies-some observations on freshwater triclads. Journal of Animal Ecology 46: 765-781

Cannings, R. J., and W. Threlfall. 1981. Horned Lark breeding biology at Cape St. Mary's, Newfoundland. Wilson Bulletin 93:519-530.

Case, T. J. 1978. On the evolution and adaptive significance of postnatal growth rates in the terrestrial vertebrates. Quarterly Review of Biology 53:243-282.

Chapman, L. B. 1955. Studies of a Tree Swallow colony. Bird-Banding 26:45-70.

Charlesworth, B. 1980. Evolution in age-structured populations. Cambridge University Press, Cambridge, England.

Charnov, E. L., and J. R. Krebs. 1974. On clutch size and fitness. Ibis 116:217-219.

Clark, C. W., and C. D. Harvell. 1992. Inducible defenses and the allocation of resources: a minimal model. American Naturalist 139:521-539.

Clobert, J., and J.-D. Lebreton. 1991. Estimation of demographic parameters in bird populations. Pages 75-104 in C. M. Perrins, J.-D. Lebreton, and G. J. M. Hirons, editors. Bird population studies: relevance to conservation and management. Oxford University Press, Oxford, England.

Cody, M. L. 1966. A general theory of clutch-size. Evolution 20:174-184.

Cole, L. C. 1954. The population consequences of life history phenomena. Quarterly Review of Biology 29:103-137.

Collias, N. E., and E. C. Collias. 1984. Nest building and bird behavior. Princeton University Press, New Jersey, USA.
Cormack, R. M. 1964. Estimates of survival from the sighting of marked animals. Biometrika 51:429-438.

Crockett, A. B., and P. L. Hansley. 1977. Coition, nesting, and postfledging behavior of Williamson's Sapsucker in Colorado. Living Bird 16:7-19.

Crowl, T. A., and A. P. Covich. 1990. Predator-induced lifehistory shifts in a freshwater snail. Science 247:949-951.

Curio, E. 1989. Is avian mortality preprogrammed? Trends in Ecology and Evolution 4:81-82.

Custer, T. W., and F. A. Pitelka. 1977. Demographic features of a Lapland Longspur population near Barrow, Alaska. Auk 94:505-525.

Dahlsten, D. L., and W. A. Copper. 1979. The use of nesting boxes to study the biology of the Mountain Chickadee (Parus gambeli) and its impact on selected forest insects. Pages 217-260 in J. G. Dickson, R. N. Conner, R. R. Fleet, J. C. Kroll, and J. A. Jackson, editors. The role of insectivorous birds in forest ecosystems. Academic Press, New York, New York, USA.

Dahlsten, D. L., W. A. Copper, D. L. Rowney, and P. K. Kleintjes. 1992. Population dynamics of the Mountain Chickadee in northern California. Pages 502-510 in D. R. McCullough and R. H. Barrett, editors. Wildlife 2001: populations. Elsevier Science Publishers, London, England.

Darley, J. A., D. M. Scott, and N. K. Taylor. 1977. Effects of age, sex, and breeding success on site fidelity of Gray Catbirds. Bird-Banding 48:145-151.

Davies, N. B. 1977. Prey selection and the search strategy of the Spotted Flycatcher (Muscicapa struata): a field study on optimal foraging. Animal Behavior 25:1016-1033.

Davis, C. M. 1978. A nesting study of the Brown Creeper. Living Bird 17:237-263.

Dhondt, A. A., F. Adriaensen, E. Matthysen, and B. Kempenaers. 1990. Nonadaptive clutch sizes in tits. Nature 348:723-725.

Dhondt, A. A., B. Kempenaers, and F. Adriaensen. 1992. Density-dependent clutch size caused by habitat heterogeneity. Journal of Animal Ecology 61:643-648.

Dixon, C. L. 1978. Breeding biology of the Savannah Sparrow on Kent Island. Auk 95:235-246.

Dobson, A. 1990. Survival rates and their relationship to life-history traits in some common British birds. Current Ornithology 7:115-147.

Drilling, N. E., and C. F. Thompson. 1988. Natal and breeding dispersal in House Wrens (Troglodytes aedon). Auk 105:480-491.

Dunning, J. B., Jr. 1984. Body weights of 686 species of North American birds. Western Bird Banding Assocation Monograph Number 1.

Eaton, S. W. 1958. A life history study of the Louisiana Waterthrush. Wilson Bulletin 70:211-236.

Edwards, S. V., and S. Naeem. 1993. The phylogenetic component of cooperative breeding in perching birds. American Naturalist 141:754-789.

Ehrlich, P. R., D. S. Dobkin, and D. Wheye. 1988. The birder's handbook. A field guide to the natural history of North American birds. Simon and Schuster, New York, New York, USA.

Ekman, J. 1984. Density-dependent seasonal mortality and population fluctuations of the temperate-zone Willow Tit (Parus montanus). Journal of Animal Ecology 53:119-134.

Ekman, J., and C. Askenmo. 1986. Reproductive cost, agespecific survival and a comparison of the reproductive strategy in two European tits (genus Parus). Evolution 40:159168.

Erwin, W. G. 1935. Some nesting habits of the Brown Thrasher. Journal of the Tennessee Academy of Science 10: 179-204.

Etges, W. J. 1989. Evolution of developmental homeostasis 
in Drosophila mojavensis. Evolutionary Ecology 3:189201.

Evans, E. W. 1978. Nesting responses of Field Sparrows (Spizella pusilla) to plant succession on a Michigan old field. Condor 80:34-40.

Evenden, F. G. 1957. Observations on nesting behavior of the House Finch. Condor 59:112-117.

Fankhauser, D. P. 1967. Survival rates in Red-winged Blackbirds. Bird-Banding 38:139-142.

1971. Annual adult survival rates of blackbirds and starlings. Bird-Banding 42:36-42.

Farner, D. S. 1945. Age groups and longevity in the American Robin. Wilson Bulletin 57:56-74.

- 1949. Age groups and longevity in the American Robin: comments, further discussion and certain revisions. Wilson Bulletin 61:68-81.

. 1955. Bird banding in the study of population dynamics. Pages 397-449 in A. Wolfson, editor. Recent studies in avian biology. University of Illinois Press, Urbana, Illinois, USA.

Felsenstein, J. 1985. Phylogenies and the comparative method. American Naturalist 125:1-15.

Finch, D. M. 1983. Brood parasitism of the Abert's Towhee: timing, frequency, and effects. Condor 85:355-359.

Fischer, D. H. 1980. Breeding biology of Curve-billed Thrashers and Long-billed Thrashers in southern Texas. Condor 82:392-397.

Forde, J. D., and N. F. Sloan. 1984. Comparison of avian survival rates derived from three methods. North American Bird Bander 9:5-7.

Foster, M. S. 1974. A model to explain molt-breeding overlap and clutch size in some tropical birds. Evolution 28:182190.

Franzreb, K. E. 1989. Ecology and conservation of the endangered Least Bell's Vireo. U.S. Fish and Wildlife Service Biological Report 89:1-17.

Fretwell, S. D. 1986. Distribution and abundance of the Dickcissel. Current Ornithology 4:211-242.

Gabriel, W., and M. Lynch. 1992. The selective advantage of reaction norms for environmental tolerance. Journal of Evolutionary Biology 5:41-59.

Garland, T., Jr., P. H. Harvey, and A. R. Ives. 1992. Procedures for the analysis of comparative data using phylogenetically independent contrasts. Systematic Biology 41: $18-32$.

Gavrilets, S., and S. M. Scheiner. 1993. The genetics of phenotypic plasticity. V. Evolution of reaction norm shape. Journal of Evolutionary Biology 6:31-48.

Geupel, G. R., and D. F. DeSante. 1990. Incidence and determinants of double brooding in Wrentits. Condor 92:6775

Gill, F. B., A. M. Mostrom, and A. L. Mack. 1993. Speciation in North American chickadees: I. Patterns of mtDNA genetic divergence. Evolution 47:195-212.

Goddard, S. V., and V. V. Board. 1967. Reproductive success of Red-winged Blackbirds in north central Oklahoma. Wilson Bulletin 79:283-300.

Goossen, J. P., and S. G. Sealy. 1982. Production of young in a dense nesting population of Yellow Warblers, Dendroica petechia, in Manitoba. Canadian Field-Naturalist 96: 189-199.

Graber, J. W. 1961. Distribution, habitat requirements, and life history of the Black-capped Vireo (Vireo atricapilla). Ecological Monographs 31:313-336.

Graber, J. W., R. R. Graber, and E. L. Kirk. 1977. Illinois birds: Picidae. Illinois Natural History Survey Biological Notes 102:1-73.

Grafen, A. 1989. The phylogenetic regression. Philosophical Transactions of the Royal Society of London, Series B 326: 119-157.
Greenberg, R. 1980. Demographic aspects of long-distance migration. Pages 493-504 in A. Keast and E. S. Morton, editors. Migrant birds in the neotropics: ecology, behavior, distribution and conservation. Smithsonian Institution Press, Washington, D.C., USA.

Grzybowski, J. A. 1990. Population and nesting ecology of the Black-capped Vireo in Texas-1988-1989. Final report, U.S. Fish and Wildlife Service, Washington, D.C., USA.

Gumbel, T., and K. A. Sullivan. 1994. Effects of drought on breeding biology of Yellow-eyed Juncos. Auk, in press.

Gustafsson, L., and W. J. Sutherland. 1988. The costs of reproduction in the Collared Flycatcher Ficedula albicollis. Nature 335:813-815.

Haartman, L. von. 1957. Adaptation in hole-nesting birds. Evolution 11:339-347.

1968. The evolution of resident versus migratory habit in birds. Some considerations. Ornis Fennica 45:1-7.

Haggerty, T. M. 1988. Aspects of the breeding biology and productivity of Bachman's Sparrow in central Arkansas. Wilson Bulletin 100:247-255.

Hann, H. W. 1937. Life history of the Ovenbird in southern Michigan. Wilson Bulletin 49:145-237.

. 1948. Longevity of the Ovenbird. Bird-Banding 19 $5-12$.

Harmeson, J. P. 1974. Breeding ecology of the Dickcissel. Auk 91:348-359.

Harvell, C. D. 1986. The ecology and evolution of inducible defenses in a marine bryozoan: cues, costs, and consequences. American Naturalist 128:810-823.

Harvey, P., and M. D. Pagel. 1991. The comparative method in evolutionary biology. Oxford University Press, Oxford, England.

Harvey, P. H., D. E. L. Promislow, and A. F. Read. 1990. Causes and correlates of life history differences among mammals. Pages 305-318 in V. Standen and R. Foley, editors. Comparative socioecology. Blackwell, Oxford, England.

Harvey, P. H., A. F. Read, and D. E. L. Promislow. 1989 Life history variation in placental mammals: unifying the data with theory. Oxford Surveys in Evolutionary Biology 6: $13-32$.

Henny, C. J. 1972. An analysis of the population dynamics of selected avian species with special reference to changes during the modern pesticide era. Wildlife Research Report Number 1. U.S. Fish and Wildlife Service, Washington, D.C., USA.

Hill, G. E. 1988. Age, plumage brightness, territory quality, and reproductive success in the Black-headed Grosbeak. Condor 90:379-388.

Hirshfield, M. F., and D. W. Tinkle. 1975. Natural selection and the evolution of reproductive effort. Proceedings of the National Academy of Science, USA 72:2227-2231.

Hofslund, P. B. 1957. Cowbird parasitism of the northern Yellow-throat. Auk 74:42-48.

1959. A life history study of the Yellowthroat, Geothlypis trichas. Proceedings of the Minnesota Academy of Sciences 27:144-174.

Hogstedt, G. 1980. Evolution of clutch size in birds: adaptive variation in relation to territory quality. Science 210:11481150.

1981. Should there be a positive or negative correlation between survival of adults in a bird population and their clutch size? American Naturalist 118:568-571.

Holcomb, L. C. 1969. Breeding biology of the American Goldfinch in Ohio. Bird-Banding 40:26-44.

1972a. Nest success and age-specific mortality in Traill's Flycatcher. Auk 89:837-841.

- 1972b. Traill's Flycatcher breeding biology. Nebraska Bird Review 40:50-68.

Holm, C. H. 1973. Breeding sex ratios, territoriality, and 
reproductive success in the Red-winged Blackbird (Agelaius phoeniceus). Ecology 54:356-365.

Holmes, R. T., and T. W. Sherry. 1992. Site fidelity of migratory warblers in temperate breeding and neotropical wintering areas: implications for population dynamics, habitat selection, and conservation. Pages 563-575 in J. M. Hagan and D. W. Johnston, editors. Ecology and conservation of neotropical migrant land birds. Smithsonian Institution Press, Washington, D.C., USA.

Holmes, R. T., T. W. Sherry, P. P. Marra, and K. E. Petit. 1992. Multiple brooding and productivity of a Neotropical migrant, the Black-throated Blue Warbler (Dendroica caerulescens), in an unfragmented temperate forest. Auk 109: $321-333$

Howell, J. C. 1942. Notes on the nesting habits of the American Robin (Turdus migratorius L.). American Midland Naturalist 28:529-603.

Hussell, D. J. 1985. On the adaptive basis for hatching asynchrony: brood reduction, nest failure and assynchronous hatching in Snow Buntings. Ornis Scandinavica 16:205212.

Hutchings, J. A. 1993. Adaptive life histories effected by age-specific survival and growth rate. Ecology 74:673-684.

Ingold, D. 1989. Nesting phenology and competition for nest sites among Red-headed and Red-bellied Woodpeckers and European Starlings. Auk 106:208-217.

Joern, W. T., and J. F. Jackson. 1983. Homogeneity of vegetational cover around the nest and avoidance of nest predation in Mockingbirds. Auk 100:497-499.

Johnson, E. J., and L. B. Best. 1980. Breeding biology of the Gray Catbird in Iowa. Iowa State Journal of Research 55: $171-183$.

Johnson, N. K., and R. M. Zink. 1983. Speciation in sapsuckers (Sphyrapicus): I. Genetic differentiation. Auk 100: $871-884$.

Johnson, N. K., R. M. Zink, and J. A. Marten. 1988. Genetic evidence for relationships in the avian family Vireonidae. Condor 90:428-445.

Johnson, R. G., and S. A. Temple. 1990. Nest predation and brood parasitism of tallgrass prairie birds. Journal of Wildlife Management 54:106-111.

Johnston, R. F. 1956. Population structure in salt marsh Song Sparrows. Part II: Density, age structure, and maintenance. Condor 58:254-272.

Jolly, G. M. 1965. Explicit estimates from capture-recapture data with both death and immigration-stochastic model. Biometrika 52:225-247.

Kale, H. W., II. 1965. Ecology and bioenergetics of the longbilled Marsh Wren Telmatodytes palustris griseus (Brewster) in Georgia salt marshes. Publications of the Nuttall Ornithological Club 5:1-142.

Karr, J. R., J. D. Nichols, K. Klimkiewicz, and J. D. Brawn. 1990. Survival rates of birds of tropical and temperate forests: will the dogma survive? American Naturalist 136: 277-291

Kelly, J. P. 1993. The effect of nest predation on habitat selection by Dusky Flycatchers in limber pine-juniper woodland. Condor 95:83-93.

Kendeigh, S. C., and S. P. Baldwin. 1937. Factors affecting yearly abundance of passerine birds. Ecological Monographs 7:91-124.

King, J. R., and L. R. Mewaldt. 1987. The summer biology of an unstable insular population of White-crowned Sparrows in Oregon. Condor 89:549-565.

Klomp, H. 1970. The determination of clutch size in birds: a review. Ardea 58:1-124.

Knapton, R. W. 1979. Breeding ecology of the Clay-colored Sparrow. Living Bird 17:137-158.

Knapton, R. W., R. V. Cartar, and J. B. Falls. 1984. A comparison of breeding ecology and reproductive success be- tween morphs of the White-throated Sparrow. Wilson Bulletin 96:60-71.

Knupp, D. M., R. B. Owen, Jr., and J. B. Dimond. 1977. Reproductive biology of American Robins in northern Maine. Auk 94:80-85.

Koenig, W. D. 1987. Morphological and dietary correlates of clutch size in North American Woodpeckers. Auk 104: 757-765.

Koenig, W. D., and R. L. Mumme. 1987. Population ecology of the cooperatively breeding Acorn Woodpecker. Princeton University Press, Princeton, New Jersey, USA.

Krementz, D. G., J. R. Sauer, and J. D. Nichols. 1989. Modelbased estimates of annual survival rate are preferable to observed maximum lifespan statistics for use in comparative life-history studies. Oikos 56:203-208.

Kridelbaugh, A. 1983. Nesting ecology of the Loggerhead Shrike in central Missouri. Wilson Bulletin 95:303-308.

Kulesza, G. 1990. An analysis of clutch-size in New World passerine birds. Ibis 132:407-422.

Lack, D. 1948. The significance of clutch size. Part 3. Some interspecific comparisons. Ibis 90:25-45.

- 1954. The natural regulation of animal numbers. Clarendon Press, Oxford, England.

. 1968. Ecological adaptations for breeding in birds. Methuen, London, England

Lack, D., and E. Lack. 1951. The breeding biology of the Swift Apus apus. Ibis 91:64-88.

Lande, R. 1982. A quantitative genetic theory of life history evolution. Ecology 63:607-615.

Lanyon, S. M. 1985. Molecular perspective on higher-level relationships in the Tyrannoidea (Aves). Systematic Zoology 34:404-418.

Lanyon, W. E. 1957. The comparative biology of the meadowlarks (Sturnella) in Wisconsin. Publications of the Nuttall Ornithological Club 1:1-67.

LaRivers, I. 1944. Observations on the nesting mortality of the Brewer Blackbird, Euphagus cyanocephalus. American Midland Naturalist 32:417-437.

Laskey, A. R. 1957. Some Tufted Titmouse life history. BirdBanding 28: 135-145

Law, R. 1979. Optimal life histories under age-specific predation. American Naturalist 114:399-417.

Lawrence, L. K. 1953. Nesting life and behavior of the Redeyed Vireo. Canadian Field-Naturalist 67:47-77.

Lebreton, J.-D., K. P. Burnham, J. Clobert, and D. R. Anderson. 1992. Modeling survival and testing biological hypotheses using marked animals: a unified approach with case studies. Ecological Monographs 62:67-118.

Leonard, M. L., and J. Picman. 1987. Nesting mortality and habitat selection by Marsh Wrens. Auk 104:491-495.

Levins, R. 1963. Theory of fitness in a heterogeneous environment. II. Developmental flexibility and niche selection. American Naturalist 97:75-90.

Lima, S. L. 1987. Clutch size in birds: a predation perspective. Ecology 68:1062-1070.

Linden, M. 1988. Reproductive trade-off between first and second clutches in the Great Tit Parus major: an experimental study. Oikos 51:285-290.

Linden, M., and A. P. Møller. 1989. Cost of reproduction and covariation of life history traits in birds. Trends in Ecology and Evolution 4:367-371.

Lively, C. M. 1986. Canalization versus developmental conversion in a spatially variable environment. American Naturalist 128:561-572.

Longcore, J. R., and R. E. Jones. 1969. Reproductive success of the Wood Thrush in a Delaware woodlot. Wilson Bulletin 81:396-406.

Lynch, M. 1980. The evolution of cladoceran life histories. Quarterly Review of Biology 55:23-42.

. 1992. The life history consequences of resource de- 
pression in Ceriodaphnia quadrangula and Daphnia ambigua. Ecology 73:1620-1629.

MacArthur, R. H., and E. O. Wilson. 1967. The theory of island biogeography. Princeton University Press, Princeton, New Jersey, USA.

Major, R. E. 1991. Breeding biology of the White-fronted Chat Ehthianura albifrons in a saltmarsh near Melbourne. Emu 91:236-249.

Marten, J. A., and N. K. Johnson. 1986. Genetic relationships of North American Cardueline finches. Condor 88:409_ 420 .

Martin, T. E. 1987. Food as a limit on breeding birds: a lifehistory perspective. Annual Review of Ecology and Systematics 18:453-487.

1988a. Habitat and area effects on forest bird assemblages: is nest predation an influence? Ecology 69:7484.

$1988 \mathrm{~b}$. On the advantage of being different: nest predation and the coexistence of bird species. Proceedings of the National Academy of Sciences, USA 85:2196-2199.

1988c. Nest placement: implications for selected life-history traits, with special reference to clutch size. American Naturalist 132:900-910.

- 1988d. Processes organizing open-nesting bird assemblages: competition or nest predation? Evolutionary Ecology 2:37-50.

-1992a. Breeding season productivity: what are the appropriate habitat features for management? Pages 455473 in J. M. Hagan and D. W. Johnston, editors. Ecology and conservation of neotropical migrant land birds. Smithsonian Institution Press, Washington, D.C., USA.

$1992 b$. Interaction of nest predation and food limitation in reproductive strategies. Current Ornithology 9: 163-197.

- $1993 a$. Nest predation among vegetation layers and habitat types: revising the dogmas. American Naturalist 141:897-913.

$1993 b$. Nest predation and nest sites: new perspectives on old patterns. BioScience 43:523-532.

. $1993 c$. Evolutionary determinants of clutch size in cavity-nesting birds: nest predation or limited breeding opportunities? American Naturalist 142:937-946.

Martin, T. E., and P. Li. 1992. Life history traits of open versus cavity-nesting birds. Ecology 73:579-592.

Martins, E. P., and T. Garland, Jr. 1991. Phylogenetic analyses of the correlated evolution of continuous characters: a simulation study. Evolution 45:534-557.

Marvil, R. E., and A. Cruz. 1989. Impact of Brown-headed Cowbird on the reproductive success of the Solitary Vireo. Auk 106:476-480.

Marzluff, J. M. 1988. Do Pinyon Jays alter nest placement based on prior experience? Animal Behavior 36:1-10.

Marzluff, J. M., and R. P. Balda. 1992. The Pinyon Jay: Behavioral ecology of a colonial and cooperative corvid. P. and A. D. Poyser, London, England.

Mayfield, H. 1960. The Kirtland's Warbler. Cranbrook Institute of Science, Bloomfield Hills, Michigan, USA.

. 1961. Nesting success calculated from exposure. Wilson Bulletin 73:255-261.

1975. Suggestions for calculating nest success. Wilson Bulletin 87:456-466.

1983. Kirtland's Warbler, victim of its own rarity? Auk 100:974-976.

Mayhew, W. M. 1958. The biology of the Cliff Swallow. Condor 60:7-37.

McCallum, D. A. 1990. Variable cone crops, migration, and dynamics of a population of Mountain Chickadees (Parus gambeli). NATO Advanced Study Institute Series, Volume G24: $103-116$.

McLennan, D. A. 1991. Integrating phylogeny and experi- mental ethology: from pattern to process. Evolution 45 : 1773-1789.

Meanley, B. 1971. Natural history of the Swainson's Warbler. North American Fauna Number 69:1-90.

Mewaldt, L. R. 1964. Effects of bird removal on a winter population of sparrows. Bird-Banding 35:184-195.

Mewaldt, L. R., and J. R. King. 1985. Breeding site faithfulness, reproductive biology, and adult survivorship in an isolated population of Cassin's Finches. Condor 87:494 510.

Michod, R. E. 1979. Evolution of life histories in response to age-specific mortality factors. American Naturalist 113 : 531-550.

Middleton, A. L. A. 1979. Influence of age and habitat on reproduction by the American Goldfinch. Ecology 60:418 432.

Miller, E. H., and E. R. Walters. 1993. Breeding biology of the Red-naped Sapsucker (Sphyrapicus nuchalis) in southcentral British Columbia. In K. Morgan, editor. Proceedings of a Workshop on Conservation and Management of Riparian Habitats. Environment Canada, Canadian Wildlife Service, in press.

Møller, A. P. 1989. Parasites, predators and nest boxes: facts and artefacts in nest box studies of birds? Oikos 56:421423.

Morton, M. L., J. L. Horstmann, and J. M. Osborn. 1972. Reproductive cycle and nesting success of the Mountain White-crowned Sparrow (Zonotrichia leucophrys oriantha) in the central Sierra Nevada. Condor 74:152-163.

Mumford, R. E. 1964. The breeding biology of the Acadian Flycatcher. Miscellaneous Publications from the Museum of Zoology of the University of Michigan Number 125:150

Murphy, E. C., and E. Haukioja. 1986. Clutch size in nidicolous birds. Current Ornithology 4:141-180.

Murphy, G. I. 1968. Pattern in life history and the environment. American Naturalist 102:391-403.

Murphy, M. T. 1983a. Ecological aspects of the reproductive biology of Eastern Kingbirds: geographic comparisons. Ecology 64:914-928.

. $1983 b$. Clutch size in the Eastern Kingbird: factors affecting nestling survival. Auk 100:326-334.

. 1983c. Nest success and nesting habits of Eastern Kingbirds and other flycatchers. Condor 85:208-219.

- 1989. Life history variability in North American breeding tyrant flycatchers: phylogeny, size or ecology? Oikos 54:3-14.

Murphy, M. T., and R. C. Fleischer. 1986. Body size, nest predation, and reproductive patterns in Brown Thrashers and other mimids. Condor 88:446-455.

Murray, B. G., Jr. 1985. Evolution of clutch size in tropical species of birds. Ornithological Monographs 36:505-519.

Newman, G. A. 1970. Cowbird parasitism and nesting success of Lark Sparrows in southern Oklahoma. Wilson Bulletin 82:304-309.

Nice, M. M. 1937. Studies in the life history of the Song Sparrow. I. Transactions of the Linnean Society, New York 4:1-247.

. 1957. Nesting success in altricial birds. Auk 74: 305-321.

Nichols, J. D., B. R. Noon, S. Lynne Stokes, and J. E. Hines. 1981. Remarks on the use of mark-recapture methodology in estimating avian population size. Studies in Avian Biology 6:121-136.

Nickell, W. P. 1965. Habitats, territory, and nesting of the catbird. American Midland Naturalist 73:433-478.

Niles, D. M. 1985. The survival of nests of American Robins in northern Delaware. Delmarva Ornithology 18:10-19.

Nilsson, S. G. 1984. The evolution of nest-site selection 
among hole-nesting birds: the importance of nest predation and competition. Ornis Scandinavica 15:167-175.

- 1986. Evolution of hole-nesting in birds: on balancing selection pressures. Auk 103:432-435.

Nolan, V., Jr. 1963. Reproductive success of birds in a deciduous scrub habitat. Ecology 44:305-313.

1978. The ecology and behavior of the Prairie Warbler Dendroica discolor. Ornithological Monographs Number 26:1-595.

Norment, C. J. 1992. Comparative breeding biology of Harris' Sparrows and Gambel's White-crowned Sparrows in the Northwest Territories, Canada. Condor 94:955-975.

Norris, R. A. 1958. Comparative biosystematics and life histories of the nuthatches, Sitta pygmaea and Sitta pusilla. University of California Publications in Zoology 56:119300 .

Nur, N. 1988. The cost of reproduction in birds: an examination of the evidence. Ardea 76:155-168.

. 1990. The cost of reproduction in birds: evaluating the evidence from manipulative and non-manipulative studies. Pages 281-296 in J. Blondel, editor. Population biology of passerine birds. Springer-Verlag, New York, New York, USA.

O'Connor, R. J. 1985. Behavioural regulation of bird populations: a review of habitat use in relation to migration and residency. Pages $105-142$ in R. M. Sibly and R. H. Smith, editors. Behavioural ecology: ecological consequences of adaptive behaviour. Blackwell Scientific Publications, Oxford, England.

. 1990. Some ecological aspects of migrants and residents. Pages 175-182 in E. Gwinner, editor. Bird migration: physiology and ecophysiology. Springer-Verlag, New York, New York, USA.

Ortego, B., and R. B. Hamilton. 1978. Nesting success and nest site selection of Red-winged Blackbirds in a freshwater swamp. Wilson Bulletin 90:457-458.

Pagel, M. D. 1992. A method for the analysis of comparative data. Journal of Theoretical Biology 156:431-442.

Partridge, L., and P. H. Harvey. 1988. The ecological context of life history evolution. Science 241:1449-1455.

Payne, R. B., and L. L. Payne. 1990. Survival estimates of Indigo Buntings: comparison of banding recoveries and local observations. Condor 92:938-946.

Perrins, C. M. 1965. Population fluctuations and clutch size in the Great Tit, Parus major L. Journal of Animal Ecology 34:601-647.

Petersen, K. L., and L. B. Best. 1987. Territory dynamics in a Sage Sparrow population: are shifts in site use adaptive? Behavioral Ecology and Sociobiology 21:351-358.

Petrinovich, L., and T. L. Patterson. 1982. The Whitecrowned Sparrow: recruitment, and population structure in the Nuttall subspecies (1975-1980). Auk 99:1-14.

Pettifor, R. A., C. M. Perrins, and R. H. McCleery. 1988. Individual optimization of clutch size in great tits. Nature 336:360-362.

Pianka, E. R. 1970. On r and K selection. American Naturalist 106:592-597.

Pickwell, G. B. 1931. The prairie Horned Lark. Transactions of the Academy of Sciencies of St. Louis 27:1-153.

Picman, J. 1980. Impact of Marsh Wrens on reproductive strategy of Red-winged Blackbirds. Canadian Journal of Zoology 58:337-350.

21981. The adaptive value of polygyny in marshnesting Red-winged Blackbirds; renesting, territory tenacity, and mate fidelity of females. Canadian Journal of Zoology 59:2284-2296.

Pinkowski, B. C. 1977. Breeding adaptations in the Eastern Bluebird. Condor 79:289-302.

Piper, W. H., and R. H. Wiley. 1990. The relationship between social dominance, subcutaneous fat and annual sur- vival in wintering White-throated Sparrows (Zonotrichia albicollis). Behavioral Ecology and Sociobiology 26:201208.

Porter, D. K., M. A. Strong, J. B. Giezentanner, and R. A. Ryder. 1975. Nest ecology, productivity, and growth of the Loggerhead Shrike on the shortgrass prairie. Southwestern Naturalist 19:429-436.

Post, W. 1974. Functional analysis of space-related behavior in the Seaside Sparrow. Ecology 55:564-575.

Post, W., and J. S. Greenlaw. 1982. Comparative costs of promiscuity and monogamy: a test of reproductive effort theory. Behavioral Ecology and Sociobiology 10:101-107.

Price, F. E., and C. E. Bock. 1983. Population ecology of the Dipper (Cinclus mexicanus) in the Front Range of Colorado. Studies in Avian Biology 7:1-84.

Price, J. B. 1936. The family relations of the Plain Titmouse. Condor 38:23-28.

Price, T., and L. Liou. 1989. Selection on clutch size in birds. American Naturalist 134:950-959.

Promislow, D. E. L., and P. H. Harvey. 1990. Living fast and dying young: a comparative analysis of life-history variation among mammals. Journal of Zoology, London 220:417-437.

Purvis, A. 1991. Comparative analysis by independent contrasts version 1.2. Department of Zoology, University of Oxford, Oxford, England.

Rendell, W. B., and R. J. Robertson. 1989. Nest-site characteristics, reproductive success and cavity availability for Tree Swallows breeding in natural cavities. Condor 91: 875-885.

Reynolds, J. D., and R. W. Knapton. 1984. Nest-site selection and breeding biology of the Chipping Sparrow. Wilson Bulletin 96:488-493.

Reynolds, T. D. 1981. Nesting of the Sage Thrasher, Sage Sparrow, and Brewer's Sparrow in southeastern Idaho. Condor 83:61-64.

Reznick, D. 1985. Costs of reproduction: an evaluation of the empirical evidence. Oikos 44:257-267.

Reznick, D. A., and H. Bryga. 1987. Life-history evolution in guppies (Poecilia reticulata): 1. Phenotypic and genetic changes in an introduction experiment. Evolution 41:13701385 .

Reznick, D. A., H. Bryga, and J. A. Endler. 1990. Experimentally induced life-history evolution in a natural population. Nature 346:357-359.

Richman, A. D., and T. Price. 1992. Evolution of ecological differences in the Old World leaf warblers. Nature 355 : 817-821.

Ricklefs, R. E. 1968. Patterns of growth in birds. Ibis 110: 419-451.

-1969. An analysis of nesting mortality in birds. Smithsonian Contributions in Zoology 9:1-48.

. 1984. The optimization of growth rate in altricial birds. Ecology 65:1602-1616.

Ritchison, G. 1983. Breeding biology of the Black-headed Grosbeak in northern Utah. Western Birds 14:159-167.

Ritter, L. V. 1983. Nesting ecology of Scrub Jays in Chico, California. Western Birds 14:147-158.

Robbins, C. S., D. K. Dawson, and B. A. Dowell. $1989 a$. Habitat area requirements of breeding forest birds of the middle Atlantic states. Wildlife Monographs Number 103: $1-34$.

Robbins, C. S., J. R. Sauer, R. S. Greenberg, and S. Droege. 1989b. Population declines in North American birds that migrate to the neotropics. Proceedings of the National A'cademy of Sciences, USA 86:7658-7662.

Roberts, J. O. L. 1971. Survival among some North American Wood Warblers. Bird-Banding 42:165-184.

Robertson, R. J. 1972. Optimal niche space of the Redwinged Blackbird (Agelaius phoeniceus). I. Nesting success 
in marsh and upland habitat. Canadian Journal of Zoology 50:247-263.

Robertson, R. J., and W. B. Rendell. 1990. A comparison of the breeding ecology of a secondary cavity-nesting bird, the Tree Swallow (Tachycineta bicolor), breeding in nest boxes and natural cavities. Canadian Journal of Zoology 68: $1046-1052$.

Rodenhouse, N. L., and R. T. Holmes. 1992. Results of experimental and natural food reductions for breeding Blackthroated Blue Warblers. Ecology 73:357-372.

Roff, D. A. 1992. Evolution of life histories. Prentice-Hall, New York, New York, USA.

Root, R. B. 1969. The behavior and reproductive success of the Blue-gray Gnatcatcher. Condor 71:16-31.

Rose, M. R., and B. Charlesworth. 1981. Genetics of life history in Drosophila melanogaster, I. Sib analysis of adult females. Genetics 97:173-186.

Roseberry, J. L., and W. D. Klimstra. 1970. The nesting ecology and reproductive performance of the Eastern Meadowlark. Wilson Bulletin 82:243-267.

Rotenberry, J. T., and J. A. Wiens. 1989. Reproductive biology of shrubsteppe Passerine birds: geographical and temporal variation in clutch size, brood size, and fledging success. Condor 91:1-14.

Roth, R. R., and R. K. Johnson. 1993. Long-term dynamics of a Wood Thrush population breeding in a forest fragment. Auk 110:37-48.

Rowley, I., M. Brooker, and E. Russell. 1991. The breeding biology of the Splendid Fairy-wren Malurs splendens: the significance of multiple broods. Emu 91:197-221.

Saether, B-E. 1987. The influence of body weight on the covariation between reproductive traits in European birds. Oikos 48:79-88.

1988. Pattern of covariation between life-history traits of European birds. Nature 331:616-617.

- 1989. Survival rates in relation to body weight in European birds. Ornis Scandinavica 20:13-21.

Sakai, H. F. 1988. Breeding biology and behavior of Hammond's and Western Flycatchers in northwestern California. Western Birds 19:49-60.

Samuel, D. E. 1971. The breeding biology of Barn and Cliff Swallows in West Virginia. Wilson Bulletin 83:284-301.

Savidge, I. R., and D. E. Davis. 1974. Survival of some common passerines in a Pennsylvania woodlot. Bird-Banding 45: $152-155$.

Schaffer, W. M. 1974a. Selection for optimal life histories: the effects of age structure. Ecology 5:291-303.

. $1974 b$. Optimal reproductive effort in fluctuating environments. American Naturalist 108:783-790.

Schluter, D., and L. Gustafsson. 1993. Maternal inheritance of condition and clutch size in the Collared Flycatcher. Evolution 47:658-667.

Schrantz, F. G. 1943. Nest life of the eastern Yellow Warbler. Auk 60:367-387.

Schulze, P. C., and C. L. Folt. 1990. Food resources, survivorship, and reproduction of the omnivorous calanoid copepod Epischura lacustris. Ecology 71:2224-2240.

Seber, G. A. F. 1965. A note on the multiple recapture census. Biometrika 52:249-259.

Sherry, T. W., and R. T. Holmes. 1992. Population fluctuations in a long-distance Neotropical migrant: demographic evidence for the importance of breeding season events in the American Redstart. Pages 431-442 in J. M. Hagan and D. J. Johnston, editors. Ecology and conservation of neotropical migrants. Smithsonian Institution Press, Washington, D.C., USA.

Shields, W. M. 1984. Factors affecting nest and site fidelity in Adirondack Barn Swallows (Hirundo rustica). Auk 101: 780-789.

Shields, W. M., and J. R. Crook. 1987. Barn Swallow co- loniality: a net cost for group breeding in the Adirondacks? Ecology 68:1373-1386.

Shine, R., and E. L. Charnov. 1992. Patterns of survival, growth, and maturation in snakes and lizards. American Naturalist 139:1257-1269.

Sibley, C. G., and J. E. Ahlquist. 1990. Phylogeny and classification of birds: a study in molecular evolution. Yale University Press, New Haven, Connecticut, USA.

Sieving, K. E. 1992. Nest predation and differential insular extinction among selected forest birds of central Panama. Ecology 73:2310-2328.

Simons, L. S. 1988. Experimental studies in the reproductive ecology of Cactus Wrens. Dissertation. Arizona State University, Tempe, Arizona, USA.

Simons, L. S., and T. E. Martin. 1990. Food limitation of avian reproduction: an experiment with the Cactus Wren. Ecology 71:869-876.

Sims, E., and W. R. DeGarmo. 1948. A study of Swainson's Warbler in West Virginia. Redstart 16:1-8.

Sinervo, B., and P. Licht. 1991. Hormonal and physiological control of clutch size, egg size, and egg shape in Sideblotched Lizards (Uta stansburiana): constraints on the evolution of lizard life histories. The Journal of Experimental Zoology 257:252-264.

Skutch, A. F. 1949. Do tropical birds rear as many young as they can nourish? Ibis 91:430-455.

. 1985. Clutch size, nesting success, and predation on nests of Neotropical birds, reviewed. Ornithological Monographs 36:575-594.

Slagsvold, T. 1982. Clutch size variation in passerine birds: the nest predation hypothesis. Oecologia 54:159-169.

- 1984. Clutch size variation of birds in relation to nest predation: on the cost of reproduction. Journal of Animal Ecology 53:945-953.

Slatkin, M. 1974. Hedging one's evolutionary bets. Nature 250:704-705.

Small, M. F., and M. L. Hunter. 1988. Forest fragmentation and avian nest predation in forested landscapes. Oecologia 76:62-64.

Smith, H. G., H. Kallander, K. Fontell, and M. Ljungstrom. 1988. Feeding frequency and parental division of labor in the double-brooded Great Tit Parus major. Behavioral Ecology and Sociobiology 22:447-453.

Smith, J. N. M. 1981. Does high fecundity reduce survival in Song Sparrows? Evolution 35:1142-1148.

Smith, K. G., and D. C. Andersen. 1982. Food, predation, and reproductive ecology of the Dark-eyed Junco in northern Utah. Auk 99:650-661.

Southern, W. E. 1958. Nesting of the Red-eyed Vireo in the Douglas Lake Region, Michigan. Jack-Pine Warbler 36: 105-130, 185-207.

Spitze, K. 1991. Chaoborus predation and life-history evolution in Daphnia pulex: temporal pattern of population diversity, fitness, and mean life history. Evolution 45:8292.

Stearns, S. C. 1976. Life-history tactics: a review of the ideas. Quarterly Review of Biology 51:3-47.

. 1992. The evolution of life histories. Oxford University Press, Oxford, England.

Stewart, P. A. 1978. Survival tables for Starlings, Redwinged Blackbirds, and Common Grackles. North American Bird Bander 3:93-94.

. 1988. Annual survival rate of Yellow-rumped Warblers. North American Bird Bander 13:106.

Stewart, R. E. 1953. A life history study of the Yellowthroat. Wilson Bulletin 65:99-115.

Stewart, R. M., R. P. Henderson, and K. Darling. 1978. Breeding ecology of the Wilson's Warbler in the high Sierra Nevada, California. Living Bird 16:83-102. 
Stibor, H. 1992. Predator induced life-history shifts in a freshwater cladoceran. Oecologia 92:162-165.

Stokes, A. W. 1950. Breeding behavior of the goldfinch. Wilson Bulletin 62:107-127.

Sturm, L. 1945. A study of the nesting activities of the American Redstart. Auk 62:189-206.

Sullivan, K. A. 1989. Predation and starvation: age-specific mortality in juvenile juncos (Junco phaenotus). Journal of Animal Ecology 58:275-286.

Sutherland, W. J. 1989. Latitudinal changes in avian life histories. Trends in Ecology and Evolution 4:273.

Sutherland, W. J., A. Grafen, and P. H. Harvey. 1986. Life history correlations and demography. Nature 320:88.

Sydeman, W. J., M. Guntert, and R. P. Balda. 1988. Annual reproductive yield in the cooperative Pygmy Nuthatch (Sitta pygmaea). Auk 105:70-77.

Tamplin, J. W., J. W. Demastes, and J. V. Remsen. 1993. Biochemical and morphometric relationships among some members of the Cardinalinae. Wilson Bulletin 105:93-113.

Tarvin, K. 1991. Microhabitat influences on predation of suburban Blue Jay nests. Thesis. University of Arkansas, Fayetteville, Arkansas, USA.

Terres, J. K. 1980. The Audubon Society encyclopedia of North American birds. Alfred A. Knopf, New York, New York, USA.

Thomas, R. H. 1946. A study of Eastern Bluebirds in Arkansas. Wilson Bulletin 58:143-183.

Thompson, C. F., and J. Nolan, Jr. 1973. Population biology of the Yellow-breasted Chat (Icteria virens L.) in southern Indiana. Ecological Monographs 43:145-171.

Threlfall, W., and J. R. Blacquiere. 1982. Breeding biology of the Fox Sparrow in Newfoundland. Journal of Field Ornithology 53:235-239.

Tuomi, J., T. Hakala, and E. Haukioja. 1983. Alternative concepts of reproductive efforts, costs of reproduction, and selection in life history evolution. American Zoologist 23: 25-34.

Tyler, J. D. 1992. Nesting ecology of the Loggerhead Shrike in southwestern Oklahoma. Wilson Bulletin 104:95-104.

Verbeek, N. A. M. 1970. Breeding ecology of the Water Pipit. Auk 87:425-451.

Walkinshaw, L. H. 1953. Life-history of the Prothonotary Warbler. Wilson Bulletin 65:152-168.

- 1966a. Studies of the Acadian Flycatcher in Michigan. Bird-Banding 37:227-257.

. 1966 b. Summer biology of Traill's Flycatcher. Wilson Bulletin 78:31-46.

- 1966c. Summer observations of the Least Flycatcher in Michigan. Jack-Pine Warbler 44:150-168.

- 1968. Eastern Field Sparrow. Pages 1217-1235 in A. C. Bent, editor. Life histories of North American cardinals, grosbeaks, buntings, towhees, finches, sparrows, and allies. Smithsonian Institution Press, Washington, D.C., USA.

Walters, J. R., P. D. Doerr, and J. H. Carter, III. 1988. The cooperative breeding system of the Red-cockaded Woodpecker. Ethology 78:275-305.

Webster, M. S. 1992. Sexual dimorphism, mating system and body size in New World blackbirds (Icterinae). Evolution 46: $1621-1641$

Weeks, H. P., Jr. 1978. Clutch size variation in the Eastern

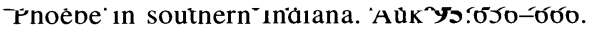

- 1979. Nesting ecology of the Eastern Phoebe in southern Indiana. Wilson Bulletin 91:441-454.

Westmoreland, D., L. B. Best, and D. E. Blockstein. 1986. Multiple brooding as a reproductive strategy: time-conserving adaptations in Mourning Doves. Auk 103:196-203.

Weston, J. G., Jr. 1947. Breeding behavior of the Blackheaded Grosbeak. Condor 49:54-73.

Wheelwright, N. T., J. Leary, and C. Fitzgerald. 1991. The costs of reproduction in Tree Swallows (Tachycineta bicolor). Canadian Journal of Zoology 69:2540-2547.

Whitcomb, R. F., C. S. Robbins, J. F. Lynch, B. L. Whitcomb, M. K. Klimkiewicz, and D. Bystrak. 1981. Effects of forest fragmentation on the avifauna of the eastern deciduous forest. Pages 125-205 in R. L. Burgess and D. M. Sharpe, editors. Forest island dynamics in man-dominated landscapes. Springer-Verlag, New York, New York, USA.

White, S. C., and G. E. Woolfenden. 1973. Breeding of the Eastern Bluebird in central Florida. Bird-Banding 44:110123.

Wilbur, H. M. 1977. Propagule size, number, and dispersal patterns in Ambystoma and Asclepias. American Naturalist 111:47-68.

Wilcove, D. S. 1985. Nest predation in forest tracts and the decline of migratory songbirds. Ecology 66:1211-1214.

Williams, G. C. 1966 a. Natural selection, the cost of reproduction, and a refinement of Lack's principle. American Naturalist 100:687-690.

. 1966b. Adaptation and natural selection. Princeton University Press, Princeton, New Jersey, USA.

Winkler, D. W. 1987. A general model for parental care. American Naturalist 130:526-543.

Wittenberger, J. F. 1978. The breeding biology of an isolated Bobolink population in Oregon. Condor 80:355-371.

Wray, T., II, K. A. Strait, and R. C. Whitmore. 1982. Reproductive success of grassland sparrows on a reclaimed surface mine in West Virginia. Auk 99:157-164.

Yahner, R. H. 1983. Site-related nesting success of Mourning Doves and American Robins in shelterbelts. Wilson Bulletin 95:573-580.

- 1991. Avian nesting ecology in small even-aged aspen stands. Journal of Wildlife Management 55:155-159.

Yahner, R. H., and D. P. Scott. 1988. Effects of forest fragmentation on depredation of artificial nests. Journal of Wildlife Management 52:158-161.

Yom-Tov, Y., R. McCleery, and D. Purchase. 1992. The survival rate of Australian passerines. Ibis 134:374-379.

Young, H. 1955. Breeding behavior and nesting of the eastern Robin. American Midland Naturalist 53:329-352.

- 1963. Age-specific mortality in the eggs and nestlings of blackbirds. Auk 80:145-155.

Zaias, J., and R. Breitwisch. 1989. Intra-pair cooperation, fledgling care, and renesting by Northern Mockingbirds (Mimus polyglottos). Ethology 80:94-110.

Zimmerman, J. L. 1963. A nesting study of the Catbird in southern Michigan. Jack-Pine Warbler 41:142-160.

- 1982. Nesting success of Dickcissels (Spiza americana) in preferred and less preferred habitats. Auk 99:292298.

298. 1983. Cowbird parasitism of Dickcissels in different habitats and at different nest densities. Wilson Bulletin 95: $7-22$.

1984. Nest predation and its relationship to habitat and nest density in Dickcissels. Condor 86:68-72.

. 1989. Philopatry and correlates of territorial fidelity in male Dickcissels. North American Bird Bander 14:8385.

Zink, R. M. 1982. Patterns of genic and morphologic variation among sparrows in the genera Zonotrichia, Melospiza, Junco, and Passerella. Auk 99:632-649.

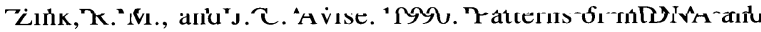
allozyme evolution in the avian genus Ammodramus. Systematic Zoology 39:148-166.

Zink, R. M., and D. L. Dittman. 1991. Evolution of brown towhees: mitochondrial DNA evidence. Condor 93:98-105.

Zink, R. M., and D. L. Dittman. 1993. Population structure and gene flow in the Chipping Sparrow and a hypothesis for evolution in the genus Spizella. Wilson Bulletin 105: $399-413$. 
Zink, R. M., D. L. Dittman, and W. L. Rootes. 1991a. Mitochondrial DNA variation and the phylogeny of Zonotrichia. Auk 108:578-584.

Zink, R. M., and N. K. Johnson. 1984. Evolutionary genetics of flycatchers. I. Sibling species in the genera Empidonax and Contopus. Systematic Zoology 33:205-216.
Zink, R. M., W. L. Rootes, and D. L. Dittman. 1991b. Mitochondrial DNA variation, population structure, and evolution of the Common Grackle (Quiscalus quiscula). Condor 93:318-329.

\section{APPENDIX 1}

Summary of clutch size, duration of the incubation period (Inc), duration of the nestling period (Nes), percentage of nests that successfully fledged at least one young (Succ), percentage of nests lost to predators (Pred), number of broods per y (Brds), annual adult survival (Surv), latitude (Lat), foraging site, and references ordered by nest site.

\begin{tabular}{|c|c|c|c|c|c|c|c|c|c|c|}
\hline Species* & $\begin{array}{l}\text { Clutch } \\
\text { size } \\
\text { (eggs } \\
\text { per } \\
\text { nest) }\end{array}$ & $\begin{array}{l}\text { Inc } \\
\text { (d) }\end{array}$ & $\begin{array}{l}\mathrm{Nes} \\
\text { (d) }\end{array}$ & $\begin{array}{c}\text { Succ } \\
(\%)\end{array}$ & $\begin{array}{c}\text { Pred } \\
(\%)\end{array}$ & $\begin{array}{c}\text { Brds } \\
\text { (no./ } \\
\text { yr) }\end{array}$ & $\begin{array}{c}\text { Surv } \\
(\%)\end{array}$ & Lat & $\begin{array}{c}\text { Foraging } \\
\text { site }\end{array}$ & References $\dagger$ \\
\hline \multicolumn{11}{|l|}{ Excavating species } \\
\hline Red-headed Woodpecker & 4.82 & 13.5 & 26.0 & 78.0 & $\ldots$ & 1.5 & 0.622 & 31 & Bark & 1,4 \\
\hline Acorn Woodpecker & 4.36 & 11.5 & 31.0 & 92.9 & 7.1 & 1.0 & 0.746 & 34 & Bark & 2,4 \\
\hline Red-bellied Woodpecker & 4.31 & 11.5 & 25.0 & 82.0 & $\cdots$ & 1.0 & 0.683 & 31 & Bark & $1,3,4$ \\
\hline Red-naped Sapsucker & 4.93 & 13.0 & 27.0 & 96.6 & 3.4 & 1.0 & 0.607 & 34 & Bark & $4,5,111$ \\
\hline Williamson's Sapsucker & 4.38 & 13.0 & 31.5 & 92.3 & 7.7 & 1.0 & $\ldots$ & 34 & Bark & $4,5,6$ \\
\hline Downy Woodpecker & 4.81 & 12.0 & 22.5 & 100.0 & 0.0 & 1.5 & 0.604 & 34 & Bark & $3,4,5,7$ \\
\hline Hairy Woodpecker & 3.93 & 14.0 & 29.0 & 87.5 & 12.5 & 1.0 & $\ldots$ & 34 & Bark & $4,5,8$ \\
\hline Red-cockaded Woodpecker & 3.27 & 11.5 & 26.0 & 72.7 & $\ldots$ & 1.0 & 0.735 & 35 & Bark & 98 \\
\hline Pileated Woodpecker & 3.80 & 18.0 & 26.0 & 83.0 & $\ldots$ & 1.0 & 0.690 & 45 & Bark & 99 \\
\hline Red-breasted Nuthatch & 5.50 & 12.0 & 19.5 & 74.1 & 25.9 & 1.0 & $\ldots$ & 34 & Bark & 5 \\
\hline Pygmy Nuthatch & 6.50 & 16.0 & 22.0 & 86.8 & 13.2 & 1.0 & 0.650 & 34 & Canopy & 5,9 \\
\hline \multicolumn{11}{|l|}{ Non-excavating species } \\
\hline Tree Swallow & 4.70 & 14.5 & 20.0 & 45.8 & 31.3 & 1.0 & 0.398 & 43 & Aerial & 100 \\
\hline Purple Martin & 4.93 & 15.5 & 28.0 & $\ldots$ & $\ldots$ & 1.0 & 0.431 & 42 & Aerial & 101 \\
\hline Cliff Swallow & 3.60 & 13.0 & 23.0 & 64.8 & $\ldots$ & 1.5 & 0.478 & 39 & Aerial & 102,103 \\
\hline Barn Swallow & 4.49 & 15.0 & 20.5 & 43.2 & 0.1 & 1.5 & 0.416 & 44 & Aerial & 103,104 \\
\hline Eastern Phoebe & 4.74 & 16.0 & 16.0 & 70.0 & 15.9 & 2.0 & 0.312 & 40 & Aerial & 105 \\
\hline Black-capped Chickadee & 6.82 & 12.0 & 16.0 & 66.3 & 19.7 & 1.5 & 0.403 & 40 & Canopy & $10,11,48$ \\
\hline Carolina Chickadee & 6.50 & 12.0 & 16.4 & 76.0 & 21.1 & 1.5 & 0.405 & 40 & Canopy & 11 \\
\hline Mountain Chickadee & 7.06 & 14.0 & 20.0 & 57.2 & 42.8 & 1.0 & 0.520 & 34 & Canopy & 5,97 \\
\hline Plain Titmouse & 6.75 & 15.0 & 18.5 & $\ldots$ & $\ldots$ & 1.0 & 0.526 & 38 & Canopy & 12 \\
\hline Tufted Titmouse & 6.00 & 13.5 & 17.5 & $\ldots$ & $\cdots$ & 2.0 & 0.416 & 36 & Canopy & 7 \\
\hline White-breasted Nuthatch & 8.00 & 12.0 & 15.0 & 60.2 & 39.8 & 1.5 & 0.350 & 34 & Bark & 3,5 \\
\hline Brown Creeper & 5.55 & 15.0 & 15.5 & 64.7 & 35.3 & 1.5 & $\ldots$ & 34 & Bark & 5,13 \\
\hline House Wren & 6.50 & 14.0 & 15.0 & 71.5 & 28.5 & 2.0 & 0.296 & 34 & Shrub & 5,14 \\
\hline Dipper & 4.30 & $\cdots$ & 16.0 & 24.5 & $\ldots$ & 2.0 & 0.456 & 40 & Aquatic & 15 \\
\hline Eastern Bluebird & 4.42 & 14.1 & 17.5 & 48.2 & 48.6 & 2.0 & 0.490 & 42 & Aerial & 16 \\
\hline Western Bluebird & 4.82 & 13.8 & 21.0 & $\ldots$ & $\ldots$ & 2.0 & 0.449 & 36 & Aerial & 106 \\
\hline European Starling & 5.36 & 12.0 & 21.0 & $\ldots$ & $\ldots$ & 2.0 & 0.485 & 42 & Ground & 17 \\
\hline Prothonotary Warbler & 4.87 & 12.5 & 12.0 & 69.0 & 31.0 & 2.0 & 0.435 & 36 & Canopy & 18 \\
\hline \multicolumn{11}{|l|}{ Ground-nesting species } \\
\hline Horned Lark & 3.36 & 11.7 & 9.5 & 56.0 & 24.9 & 2.0 & $\ldots$ & 47 & Ground & 19 \\
\hline Water Pipit & 4.60 & 14.4 & 14.4 & 58.5 & 22.3 & 1.0 & $\ldots$ & 45 & Ground & 20 \\
\hline Orange-crowned Warbler & 4.46 & 14.0 & 11.0 & 50.0 & 50.0 & 1.0 & $\ldots$ & 34 & Shrub & 5 \\
\hline Virginia's Warbler & 3.60 & 13.0 & 12.0 & 58.0 & 42.0 & 1.0 & $\ldots$ & 34 & Canopy & 5 \\
\hline Kirtland's Warbler & 4.63 & 14.1 & 11.4 & 30.0 & 40.1 & 1.0 & 0.650 & 44 & Shrub & 21 \\
\hline Black-and-White Warbler & 4.76 & 11.0 & 11.0 & 73.7 & 26.3 & 1.0 & $\ldots$ & 38 & Bark & 5 \\
\hline Worm-eating Warbler & 4.76 & 13.0 & 11.0 & 72.7 & 25.6 & 1.0 & 0.700 & 39 & Canopy & 5,109 \\
\hline Ovenbird & 4.70 & 12.0 & 9.0 & 45.2 & 24.5 & 1.0 & 0.638 & 42 & Ground & $5,22,47,63 a$ \\
\hline Northern Waterthrush & 4.28 & 13.0 & 10.0 & $\ldots$ & $\ldots$ & 1.0 & 0.647 & 42 & Ground & $5,63 a$ \\
\hline Louisiana Waterthrush & 5.80 & 12.5 & 10.0 & 70.0 & $\ldots$ & 1.0 & $\ldots$ & 42 & Ground & 23 \\
\hline Kentucky Warbler & 4.62 & 12.5 & 9.0 & 70.0 & 30.0 & 1.0 & 0.648 & 38 & Ground & 5,112 \\
\hline Wilson's Warbler & 4.18 & 12.8 & 9.7 & 60.3 & 34.9 & 1.0 & 0.563 & 38 & Shrub & 24 \\
\hline Red-faced Warbler & 4.53 & 13.0 & 12.0 & 52.0 & 48.0 & 1.0 & 0.677 & 34 & Canopy & 5 \\
\hline Bachman's Sparrow & 4.00 & 13.5 & 9.0 & 35.7 & 45.8 & 2.0 & $\ldots$ & 38 & Ground & 25 \\
\hline Vesper Sparrow & 3.75 & 12.0 & 9.0 & 31.4 & 52.9 & 2.5 & 0.500 & 40 & Ground & 26 \\
\hline Lark Sparrow & 3.61 & 11.5 & 9.5 & 45.2 & 38.7 & 2.0 & $\ldots$ & 34 & Ground & 27 \\
\hline Savannah Sparrow & 4.04 & 11.8 & 9.0 & 40.8 & 43.4 & 2.5 & 0.485 & 50 & Ground & $26,26 a, 28$ \\
\hline
\end{tabular}


APPENDIX 1 Continued

\begin{tabular}{|c|c|c|c|c|c|c|c|c|c|c|}
\hline Species* & $\begin{array}{c}\text { Clutch } \\
\text { size } \\
\text { (eggs } \\
\text { per } \\
\text { nest) }\end{array}$ & $\begin{array}{l}\text { Inc } \\
\text { (d) }\end{array}$ & $\begin{array}{l}\text { Nes } \\
\text { (d) }\end{array}$ & $\begin{array}{c}\text { Succ } \\
(\%)\end{array}$ & $\begin{array}{l}\text { Pred } \\
(\%)\end{array}$ & $\begin{array}{c}\text { Brds } \\
\text { (no./ } \\
\text { yr) }\end{array}$ & $\begin{array}{l}\text { Surv } \\
(\%)\end{array}$ & Lat & $\begin{array}{l}\text { Foraging } \\
\text { site }\end{array}$ & References $\dagger$ \\
\hline Grasshopper Sparrow & 4.39 & 11.5 & 9.0 & 39.2 & 58.9 & 2.0 & $\ldots$ & 42 & Ground & $26,26 a$ \\
\hline White-throated Sparrow & 4.27 & 13.0 & 9.0 & 44.9 & 41.3 & 1.5 & 0.543 & 46 & Ground & 3,29 \\
\hline Harris' Sparrow & 4.26 & 12.8 & 9.3 & 47.7 & 30.0 & 1.0 & 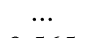 & 63 & Ground & 96 \\
\hline Dark-eyed Junco & 3.94 & 11.8 & 10.0 & 59.9 & 31.7 & 2.0 & 0.565 & 38 & Ground & $3,5,30$ \\
\hline Yellow-eyed Junco & 3.40 & 13.0 & 10.5 & 48.1 & $\ldots$ & 2.0 & 0.588 & 34 & Ground & 107 \\
\hline Lapland Longspur & 5.06 & 12.0 & 7.0 & 49.4 & 32.4 & 1.0 & 0.677 & 71 & Ground & 31 \\
\hline Snow Bunting & 5.23 & 12.0 & 13.5 & $\ldots$ & 27.9 & 1.0 & $\cdots$ & 71 & Ground & 32 \\
\hline Bobolink & 5.12 & 11.5 & 12.0 & 62.8 & 29.8 & 1.0 & 0.590 & 45 & Ground & $26 a, 33$ \\
\hline Eastern Meadowlark & 4.49 & 14.1 & 11.0 & 37.5 & 48.6 & 2.0 & 0.560 & 41 & Ground & 34,35 \\
\hline Western Meadowlark & 4.83 & 14.8 & 11.0 & 42.3 & 46.9 & 2.0 & 0.550 & 44 & Ground & $26 a, 35$ \\
\hline \multicolumn{11}{|c|}{ Shrub- or low-foliage-nesting species } \\
\hline Acadian Flycatcher & 2.93 & 14.2 . & 13.7 & 57.4 & 27.9 & 1.5 & 0.460 & 43 & Aerial & 36,37 \\
\hline Willow Flycatcher & 3.63 & 13.9 & 13.5 & 49.3 & 44.2 & 1.0 & 0.450 & 43 & Aerial & 38 \\
\hline Least Flycatcher & 3.95 & 14.0 & 14.8 & 47.4 & 53.3 & 1.0 & 0.420 & 43 & Aerial & 37,39 \\
\hline Dusky Flycatcher & 3.60 & 13.5 & 18.0 & 38.0 & 55.5 & 1.0 & 0.577 & 43 & Aerial & 40,41 \\
\hline Cordilleran Flycatcher & 3.30 & 16.0 & 16.3 & 17.9 & 58.9 & 1.0 & $\cdots$ & 39 & Aerial & 5,42 \\
\hline Sedge Wren & 6.26 & 14.0 & 13.0 & 68.2 & 22.7 & 2.0 & $\ldots$ & 47 & Shrub & 43 \\
\hline Marsh Wren & 4.91 & 13.1 & 12.5 & 39.4 & 46.9 & 2.0 & $\ldots$ & 31 & Shrub & 44 \\
\hline Cactus Wren & 3.43 & 16.0 & 20.9 & 68.8 & 28.6 & 3.0 & 0.439 & 32 & Shrub & 108 \\
\hline Blue-gray Gnatcatcher & 4.25 & 15.0 & 12.5 & 24.4 & $\ldots$ & 2.0 & $\ldots$ & 34 & Canopy & 45 \\
\hline Hermit Thrush & 3.82 & 13.0 & 13.0 & 6.0 & 94.0 & 2.0 & $\ldots$ & 34 & Ground & 5 \\
\hline Wood Thrush & 3.29 & 13.5 & 12.0 & 33.3 & 52.5 & 2.0 & 0.619 & 39 & Ground & 46,47 \\
\hline Swainson's Thrush & 3.81 & 12.5 & 12.0 & $\ldots$ & $\ldots$ & 2.0 & 0.570 & 44 & Ground & 5,37 \\
\hline American Robin & 3.36 & 13.0 & 13.6 & 48.8 & 40.2 & 2.5 & 0.546 & 46 & Ground & $5,40,47-49$ \\
\hline Wrentit & 3.74 & 15.5 & 15.5 & 50.4 & $\cdots$ & 1.5 & 0.685 & 38 & Shrub & 50 \\
\hline Gray Catbird & 3.75 & 13.1 & 10.9 & 53.2 & 31.2 & 2.0 & 0.577 & 42 & Shrub & $47,51,52$ \\
\hline Northern Mockingbird & 3.91 & 12.2 & 12.0 & 49.7 & 47.1 & 2.5 & 0.490 & 33 & Shrub & 3,53 \\
\hline Brown Thrasher & 3.72 & 13.1 & 11.3 & 43.5 & 29.0 & 2.0 & $\ldots$ & 39 & Ground & 54,93 \\
\hline Sage Thrasher & 3.50 & 15.0 & 12.3 & 45.0 & $\ldots$ & 2.0 & $\ldots$ & 43 & Shrub & 55 \\
\hline Curve-billed Thrasher & 3.80 & 14.0 & 14.0 & 43.8 & 40.2 & 2.5 & $\ldots$ & 28 & Ground & 56 \\
\hline Loggerhead Shrike & 5.85 & 16.6 & 17.6 & 61.7 & 19.4 & 2.0 & 0.470 & 41 & Shrub & 57 \\
\hline Bell's Vireo & 3.39 & 14.0 & 11.0 & 11.4 & 11.4 & 2.0 & $\cdots$ & 39 & Shrub & 58 \\
\hline Black-capped Vireo & 3.63 & 15.5 & 12.4 & 18.3 & 24.1 & 2.0 & 0.545 & 34 & Shrub & 59 \\
\hline Black-throated Blue Warbler & 3.91 & 12.0 & 9.0 & 60.9 & 42.8 & 2.0 & 0.460 & 44 & Shrub & 60 \\
\hline Prairie Warbler & 3.89 & 11.9 & 9.3 & 22.3 & 61.8 & 2.0 & 0.546 & 39 & Shrub & 61 \\
\hline Swainson's Warbler & 3.33 & 14.5 & 11.0 & 33.3 & $\ldots$ & 1.5 & $\ldots$ & 35 & Shrub & 62 \\
\hline MacGillivray's Warbler & 3.83 & 13.0 & 10.0 & 50.7 & 49.3 & 2.0 & 0.491 & 34 & Shrub & 5,40 \\
\hline Common Yellowthroat & 3.90 & 12.0 & 8.3 & 44.4 & 14.5 & 2.0 & 0.542 & 44 & Shrub & 63 \\
\hline Hooded Warbler & 3.58 & 12.0 & 8.5 & 53.0 & 47.0 & 2.0 & 0.547 & 38 & Shrub & 5,110 \\
\hline Yellow-breasted Chat & 3.54 & 11.0 & 8.0 & 19.7 & 66.9 & 2.0 & $\ldots$ & 35 & Shrub & 64,67 \\
\hline Northern Cardinal & 3.12 & 12.5 & 9.5 & 36.4 & 54.0 & 2.5 & 0.561 & 37 & Shrub & $3,48,52,65,67$ \\
\hline Indigo Bunting & 3.23 & 12.5 & 9.5 & 36.4 & 54.0 & 3.0 & 0.476 & 42 & Shrub & 52,66 \\
\hline Painted Bunting & 3.75 & 11.5 & 13.0 & 58.8 & 35.3 & 3.0 & $\ldots$ & 31 & Shrub & 67 \\
\hline Dickcissel & 3.95 & 12.0 & 9.0 & 33.9 & 48.8 & 1.5 & $\ldots$ & 39 & Shrub & 68 \\
\hline Green-tailed Towhee & 3.82 & 12.0 & 12.0 & 22.0 & 78.0 & 2.0 & 0.560 & 34 & Ground & 5,40 \\
\hline Rufous-sided Towhee & 3.75 & 12.5 & 11.0 & 48.1 & 51.9 & 2.0 & 0.556 & 41 & Ground & 47 \\
\hline Abert's Towhee & 2.96 & $\ldots$ & 12.5 & 27.5 & 63.8 & $\ldots$ & $\ldots$ & 34 & Ground & 69 \\
\hline Chipping Sparrow & 4.00 & 11.5 & 9.0 & 58.8 & 41.2 & 2.0 & $\ldots$ & 46 & Ground & 70 \\
\hline Clay-colored Sparrow & 4.11 & 11.0 & 9.0 & 42.7 & 52.4 & 1.5 & 0.566 & 47 & Ground & $26 a, 71$ \\
\hline Brewer's Sparrow & 3.04 & 13.0 & 8.5 & 79.5 & 20.5 & $\ldots$ & $\ldots$ & 43 & Ground & 72 \\
\hline Field Sparrow & 3.56 & 11.2 & 8.3 & 35.1 & 60.4 & 2.5 & 0.460 & 41 & Ground & $26,73,81 a$ \\
\hline Sage Sparrow & 2.93 & 14.2 & 10.0 & 56.4 & 43.2 & 2.0 & $\cdots$ & 43 & Ground & $72,72 a$ \\
\hline Sharp-tailed Sparrow & 3.86 & 11.0 & 10.0 & 24.3 & $\ldots$ & 2.0 & 0.537 & 43 & Ground & 74 \\
\hline Seaside Sparrow & 3.81 & 12.4 & 9.6 & 31.9 & 6.9 & 2.0 & 0.550 & 43 & Shrub & 74 \\
\hline Song Sparrow & 3.60 & 12.6 & 10.0 & 42.8 & 28.1 & 2.0 & 0.554 & 39 & Shrub & 40,75 \\
\hline White-crowned Sparrow & 3.56 & 12.6 & 10.0 & 37.4 & 51.1 & 2.5 & 0.504 & 39 & Ground & 40,76 \\
\hline Red-winged Blackbird & 3.49 & 12.6 & 12.1 & 30.7 & 44.4 & 2.0 & 0.530 & 43 & Ground & $52,77,78$ \\
\hline Yellow-headed Blackbird & 3.18 & 13.1 & 12.8 & 30.0 & 34.4 & 1.5 & 0.621 & 44 & Ground & 78,79 \\
\hline Brewer's Blackbird & 4.87 & 13.0 & 13.5 & 39.4 & 45.5 & 1.5 & $\ldots$ & 39 & Ground & 80 \\
\hline American Goldfinch & 4.88 & 12.3 & 13.5 & 45.0 & 46.8 & 2.0 & 0.440 & 42 & Shrub & $3,81,81 a$ \\
\hline \multicolumn{11}{|c|}{ Subcanopy/canopy-nesting species } \\
\hline Cassin's Kingbird & 3.40 & 18.5 & 16.5 & 28.7 & 42.6 & 1.5 & $\ldots$ & 33 & Aerial & 82 \\
\hline Western Kingbird & 3.81 & 8.5 & 16.5 & 20.2 & 37.6 & 1.0 & $\cdots$ & 33 & Aerial & 82 \\
\hline Eastern Kingbird & 3.56 & 14.7 & 16.4 & 47.0 & 32.7 & 1.0 & 0.433 & 42 & Aerial & 83 \\
\hline Blue Jay & 4.70 & 17.0 & 19.0 & 52.0 & 38.4 & 1.0 & 0.620 & 36 & Canopy & $48,52,84$ \\
\hline
\end{tabular}


APPENDIX 1 Continued.

\begin{tabular}{|c|c|c|c|c|c|c|c|c|c|c|}
\hline Species* & $\begin{array}{c}\text { Clutch } \\
\text { size } \\
\text { (eggs } \\
\text { per } \\
\text { nest) }\end{array}$ & $\begin{array}{l}\text { Inc } \\
\text { (d) }\end{array}$ & $\begin{array}{l}\text { Nes } \\
\text { (d) }\end{array}$ & $\begin{array}{c}\text { Succ } \\
(\%)\end{array}$ & $\begin{array}{l}\text { Pred } \\
(\%)\end{array}$ & $\begin{array}{c}\text { Brds } \\
\text { (no./ } \\
\text { yr) }\end{array}$ & $\begin{array}{c}\text { Surv } \\
(\%)\end{array}$ & Lat & $\begin{array}{l}\text { Foraging } \\
\text { site }\end{array}$ & References $\dagger$ \\
\hline Scrub Jay & 4.80 & 18.2 & 20.0 & 54.0 & 29.5 & 1.0 & 0.760 & 38 & Shrub & 85 \\
\hline Pinyon Jay & 3.94 & 16.5 & 21.0 & 30.5 & 41.2 & 1.0 & 0.739 & 35 & Canopy & 86 \\
\hline American Crow & 4.0 & 18.3 & 28.8 & 32.8 & 49.1 & $\ldots$ & $\ldots$ & 49 & Canopy & 87 \\
\hline Solitary Vireo & 3.74 & 15.0 & 13.0 & 45.3 & 18.0 & 1.5 & $\ldots$ & 40 & Canopy & 88 \\
\hline Warbling Vireo & 3.57 & 13.0 & 13.0 & 55.0 & 45.0 & 2.0 & $\ldots$ & 34 & Canopy & 5 \\
\hline Red-eyed Vireo & 3.18 & 13.0 & 10.5 & 50.6 & 24.9 & 2.0 & 0.553 & 48 & Canopy & 89 \\
\hline Yellow Warbler & 4.30 & 11.0 & 9.5 & 49.8 & 34.2 & 1.5 & 0.573 & 50 & Shrub & $37,40,63 a, 90$ \\
\hline Yellow-rumped Warbler & 4.00 & 13.0 & 13.0 & 47.0 & 53.0 & 1.5 & 0.528 & 34 & Canopy & 5,91 \\
\hline American Redstart & 3.20 & 11.0 & 8.5 & 55.2 & 37.8 & 1.0 & 0.670 & 43 & Canopy & 37,92 \\
\hline Scarlet Tanager & 4.00 & 13.5 & 12.0 & 67.4 & 32.6 & 1.5 & 0.611 & 39 & Canopy & 5,47 \\
\hline Western Tanager & 3.61 & 13.0 & 13.0 & 53.8 & 46.2 & 1.0 & $\ldots$ & 34 & Canopy & 5 \\
\hline Rose-breasted Grosbeak & $\ldots$ & 13.5 & 10.5 & 50.0 & 50.0 & 1.5 & $\ldots$ & 42 & Canopy & 52 \\
\hline Black-headed Grosbeak & 3.16 & 12.7 & 12.1 & 66.1 & 34.0 & 1.5 & $\ldots$ & 37 & Canopy & 5,94 \\
\hline House Finch & 4.40 & 13.3 & 15.1 & 44.9 & 45.8 & 2.0 & 0.552 & 44 & Canopy & 95 \\
\hline
\end{tabular}

* Scientific names presented in Appendix 2.

$\dagger$ References (for complete citation, refer to Literature Cited section of text): (1) Ingold 1989, unpublished data; (2) Koenig and Mumme 1987; (3) Karr et al 1990; (4) Koenig 1987; (5) Martin and Li 1992, Martin 1988c, 1993a, T. E. Martin, unpublished data; P. Li and T. E. Martin, unpublished data; (6) Crockett and Hansley 1977; (7) Laskey 1957, Forde and Sloan 1984; (8) Graber et al. 1977; (9) Norris 1958, Sydeman et al. 1988; (10) Brittingham and Temple 1988; (11) Brewer 1963, Albano 1992; (12) Price 1936; (13) Davis 1978; (14) Kendeigh and Baldwin 1937, Drilling and Thompson 1988; (15) Price and Bock 1983; (16) Thomas 1946, White and Woolfenden 1973, Pinkowski 1977; (17) Fankhauser 1971, Stewart 1978; (18) Walkinshaw 1953, L. Petit, unpublished data; (19) Pickwell 1931, Cannings and Threlfall 1981; (20) Verbeek 1970; (21) Mayfield 1960, 1983; (22) Hann 1937, 1948; (23) Eaton 1958; (24) Stewart et al. 1978; (25) Haggerty 1988; (26) Wray et al. 1982; (26a) Johnson and Temple 1990; (27) Newman 1970; (28) Dixon 1978, Bedard and LaPointe 1984; (29) Knapton et al. 1984, Piper and Wiley 1990; (30) Baylor and Whitney 1976, Smith and Andersen 1982; (31) Custer and Pitelka 1977; (32) Hussell 1985; (33) Wittenberger 1978; (34) Roseberry and Klimstra 1970; (35) Lanyon 1957; (36) Mumford 1964, Walkinshaw 1966a; (37) Nichols et al. 1981; (38) Walkinshaw 1966b, Berger 1967, Holcomb 1972a, $b$; (39) Walkinshaw 1966c; Briskie and Sealy 1989; (40) King and Mewaldt 1987; (41) Kelly 1993; (42) Sakai 1988; (43) Burns 1982; (44) Kale 1965, Leonard and Picman 1987; (45) Root 1969; (46) Longcore and Jones 1969, Roth and Johnson 1993; (47) Savidge and Davis 1974, Yahner 1991; (48) Henny 1972; (49) Howell 1942, Farner 1945, 1949, Young 1955, Knupp et al. 1977, Yahner 1983, Niles 1985; (50) Geupel and Desante 1990; (51) Zimmerman 1963, Nickell 1965, Darley et al. 1977, Johnson and Best 1980; (52) Best and Stauffer 1980; (53) Joern and Jackson 1983; (54) Murphy and Fleischer 1986; (55) Reynolds 1981; (56) Fischer 1980; (57) Porter et al. 1975, Kridelbaugh 1983, Tyler 1992; (58) Barlow 1962, Franzreb 1989; (59) Graber 1961, Grzybowski 1990; (60) Holmes and Sherry 1992, Rodenhouse and Holmes 1992; (61) Nolan 1978; (62) Sims and DeGarmo 1948, Meanley 1971; (63) Stewart 1953, Hofslund 1957, 1959; (63a) Roberts 1971; (64) Thompson and Nolan 1973; (65) Farner 1955; (66) Payne and Payne 1990; (67) Barber 1993; (68) Harmeson 1974, Zimmerman 1982, 1983, 1984, 1989, Fretwell 1986; (69) Finch 1983; (70) Reynolds and Knapton 1984; (71) Knapton 1979; (72) Rotenberry and Wiens 1989; (72a) Petersen and Best 1987; (73) Walkinshaw 1968, Best 1978, Evans 1978; (74) Post 1974, Post and Greenlaw 1982; (75) Nice 1937, Johnston 1956, Smith 1981; (76) Mewaldt 1964, Morton et al. 1972, Petrinovich and Patterson 1982; (77) Goddard and Board 1967, Fankhauser 1967, 1971, Holm 1973, Robertson 1972, Caccamise 1977, Ortego and Hamilton 1978, Stewart 1978, Picman 1980, 1981; (78) Young 1963; (79) Bray et al. 1979; (80) LaRivers 1944; (81) Stokes 1950, Holcomb 1969, Middleton 1979; (81a) Nolan 1963; (82) Blancher and Robertson 1985; (83) Murphy 1983a, $b ;(84)$ Tarvin 1991; (85) Ritter 1983; (86) Balda and Bateman 1972, Marzluff 1988, Marzluff and Balda 1992; (87) Butler et al. 1984; (88) Marvil and Cruz 1989; (89) Lawrence 1953, Southern 1958;(90) Schrantz 1943, Goosen and Sealy 1982; (91) Stewart 1988; (92) Sturm 1945, Sherry and Holmes 1992; (93) Erwin 1935; (94) Weston 1947, Ritchison 1983, Hill 1988; (95) Evenden 1957; (96) Norment 1992; (97) Dahlsten and Copper 1979, McCallum 1990, Dahlsten et al. 1992; (98) Walters et al. 1988; (99) Bull and Meslow 1988; (100) Chapman 1955, Rendell and Robertson 1989, Robertson and Rendell 1990, Wheelwright et al. 1991; (101) Allen and Nice 1957; (102) Mayhew 1958, Brown and Brown 1992; (103) Samuel 1971; (104) Shields 1984, Shields and Crook 1987; (105) Weeks 1978, 1979, H. P. Weeks, Jr., unpublished data; (106) J. Dickinson and W. Koenig, unpublished data; (107) Sullivan 1989, K. A. Sullivan, unpublished data, Gumbel and Sullivan 1994; (108) Anderson and Anderson 1973, Simons 1988; (109) L. Hanners and S. Patton, unpublished data; (110) Stutchbury, unpublished data; (111) Miller and Walters 1993; (112) V. MacDonald, unpublished data. 


\section{APPENDIX 2}

Scientific and common names of bird species mentioned in the text or in Appendix 1. The scientific name follows the common names for each species.

Red-headed Woodpecker Melanerpes erythrocephalus

Acorn Woodpecker Melanerpes formicovorus

Red-bellied Woodpecker Melanerpes carolinus

Red-naped Sapsucker Sphyrapicus varius

Williamson's Sapsucker Sphyrapicus thyroideus

Red-cockaded Woodpecker Picoides borealis

Downy Woodpecker Picoides pubescens

Hairy Woodpecker Picoides villosus

Northern Flicker Colaptes auratus

Pileated Woodpecker Dryocopus pileatus

Acadian Flycatcher Empidonax virescens

Willow Flycatcher Empidonax traillii

Least Flycatcher Empidonax minimus

Dusky Flycatcher Empidonax oberholseri

Cordilleran Flycatcher Empidonax difficilis

Eastern Phoebe Sayornis phoebe

Cassin's Kingbird Tyrannus vociferans

Western Kingbird Tyrannus verticalis

Eastern Kingbird Tyrannus tyrannus

Horned Lark Alauda arvensis

Blue Jay Cyanocitta cristata

Scrub Jay Aphelocoma coerulescens

Pinyon Jay Gymnorhinus cyanocephalus

Steller's Jay Cyanocitta stelleri

Northwestern Crow Corvus caurinus

Black-capped Chickadee Parus atricapillus

Carolina Chickadee Parus carolinensis

Mountain Chickadee Parus gambeli

Plain Titmouse Parus inornatus

Tufted Titmouse Parus bicolor

Red-breasted Nuthatch Sitta canadensis

White-breasted Nuthatch Sitta carolinensis

Pygmy Nutatch Sitta pygmaea

Brown Creeper Certhia americana

Cactus Wren Campylorhynchus brunneicapillus

House Wren Troglodytes aedon

Sedge Wren Cistothorus platensis

Marsh Wren Cistothorus palustris

Dipper Cinclus mexicanus

Blue-gray Gnatcatcher Polioptila caerulea

Eastern Bluebird Sialia sialis

Western Bluebird Sialia mexicana

Swainson's Thrush Catharus ustulatus

Hermit Thrush Catharus guttatus

Wood Thrush Hylocichla mustelina

American Robin Turdus migratorius

Wrentit Chamaea fasciata

Gray Catbird Dumetella carolinensis

Northern Mockingbird Mimus polyglottus

Sage Thrasher Oreoscoptes montanus

Brown Thrasher Toxostoma rufum

Curve-billed Thrasher Toxostoma curvirostra

Water Pipit Anthus spinoletta

Loggerhead Shrike Lanius ludovicianus

European Starling Sturnus vulgaris

Bell's Vireo Vireo bellii

Black-capped Vireo Vireo atricapillus

Solitary Vireo Vireo solitarius

Warbling Vireo Vireo gilvus

Red-eyed Vireo Vireo olivaceus
Orange-crowned Warbler Vermivora celata

Virginia's Warbler Vermivora virginiae

Yellow Warbler Dendroica petechia

Black-throated Blue Warbler Dendroica caerulescens

Yellow-rumped Warbler Dendroica coronata

Kirtland's Warbler Dendroica kirtlandii

Prairie Warbler Dendroica discolor

Black-and-White Warbler Mniotilta varia

American Redstart Setophaga ruticilla

Prothonotary Warbler Protonotaria citrea

Worm-eating Warbler Helmitheros vermivorus

Swainson's Warbler Limnothlypis swainsonii

Ovenbird Seiurus aurocapillus

Louisiana Waterthrush Seiurus motacilla

Kentucky Warbler Oporornis formosus

MacGillivray's Warbler Oporornis tolmiei

Common Yellowthroat Geothlypis trichas

Hooded Warbler Wilsonia citrina

Wilson's Warbler Wilsonia pusilla

Red-faced Warbler Cardellina rubrifrons

Yellow-breasted Chat Icteria virens

Scarlet Tanager Piranga olivacea

Western Tanager Piranga ludoviciana

Northern Cardinal Cardinalis cardinalis

Rose-breasted Grosbeak Pheucticus ludovicianus

Black-headed Grosbeak Pheucticus melanocephalus

Indigo Bunting Passerina cyanea

Painted Bunting Passerina ciris

Dickcissel Spiza americana

Green-tailed Towhee Pipilo chlorurus

Rufous-sided Towhee Pipilo erythrophthalmus

Abert's Towhee Pipilo aberti

Bachman's Sparrow Aimophila aestivalis

Chipping Sparrow Spizella passerina

Clay-colored Sparrow Spizella pallida

Brewer's Sparrow Spizella breweri

Field Sparrow Spizella pusilla

Vesper Sparrow Pooecetes gramineus

Lark Sparrow Chondestes grammacus

Sage Sparrow Amphispiza belli

Savannah Sparrow Passerculus sandwichensis

Grasshopper Sparrow Ammodramus savannarum

Sharp-tailed Sparrow Ammodramus caudacutus

Seaside Sparrow Ammodramus maritimus

Song Sparrow Melospiza melodia

White-throated Sparrow Zonotrichia albicollis

White-crowned Sparrow Zonotrichia leucophrys

Dark-eyed Junco Junco hyemalis

Lapland Longspur Calcarius lapponicus

Snow Bunting Plectrophenax nivalis

Bobolink Dolichonyx oryzivorus

Red-winged Blackbird Agelaius phoeniceus

Eastern Meadowlark Sturnella magna

Western Meadowlark Sturnella neglecta

Yellow-headed Blackbird Xanthocephalus xanthocephalus

Brewer s Blackbird Euphagus cyanocephalus

House Finch Carpodacus mexicanus

American Goldfinch Carduelis tristis

Brown-headed Cowbird Molothrus ater 